\title{
POST-OSLO PEACE INITIATIVES AND THE DISCOURSE OF PALESTINIAN-ISRAELI RELATIONS
}

\author{
Sean McMahon ${ }^{1}$ \\ American University in Cairo
}

\begin{abstract}
Abstracr:
The author's argument is that the efforts made by the Obama administration to realize Palestinian-Israeli reconciliation will, like all "peace" initiatives before them, ultimately exacerbate direct and structural violence between the two parties. He makes this argument in four stages. First, he explains his Foucault-inspired discourse analysis. Second, he describes and historicizes the discourse of Palestinian-Israeli relations. More specifically, he identifies the three persistent practices, three silences and three rules of formation that constitute the discourse. Third, he demonstrates how all post-Oslo peace initiatives, the Roadmap and the Geneva Accord for example, were articulations of, and rearticulated, this discourse and consequently (re-)produced PalestinianIsraeli violence. Fourth and finally, he argues that if the Obama administration is to realize Palestinian-Israeli peace, it must violate the determinant rule of the discourse and talk about Israel's ethnic cleansing of Palestine.
\end{abstract}

Keywords: Oslo Process, Obama, discourse, Zionism, transfer, settlement, Roadmap, Geneva Accord, Disengagement Plan, Palestinian-Israeli peace

\section{Resumen:}

El argumento del autor se basa en que los esfuerzos hechos por la Administración Obama para llevar a cabo la reconciliación palestino-israelí, como todas las iniciativas "de paz" anteriores a ellos, exacerbará en última instancia la violencia estructural y directa entre las dos partes. Desarrolla este argumento en cuatro etapas. En primer lugar, explica su análisis de discurso inspirado en Foucault. En segundo lugar, describe el proceso histórico del discurso de las relaciones entre palestinos e israelíes. Más concretamente, identifica las tres prácticas persistentes, los tres silencios y las tres reglas de formación que constituyen el discurso. En tercer lugar, demuestra cómo todas iniciativas de paz posteriores a Oslo, la Hoja de Ruta y el Acuerdo de Ginebra, por ejemplo, fueron articulaciones, y rearticuladas, de este discurso y en consecuencia (re-) producen la violencia entre palestinos e israelíes. En cuarto y último lugar, discute acerca de si la Administración Obama desea lograr la paz entre palestinos e israelíes, debe violar la regla determinante del discurso y hablar sobre la limpieza étnica israelí de Palestina.

Palabras clave: Proceso de Oslo, Obama, discurso, Sionismo, transferencia, asentamiento, Hoja de Ruta, Acuerdo de Génova, Plan de Desconexión, paz israelo-palestina.

Copyright C UNISCI, 2011.

Las opiniones expresadas en estos artículos son propias de sus autores, y no reflejan necesariamente la opinión de UNISCI. The views expressed in these articles are those of the authors, and do not necessarily reflect the views of UNISCI

\footnotetext{
${ }^{1}$ Sean McMahon is Assistant Professor in the Department of Political Science in The American University in Cairo, Egypt. Email: smcmahon@aucegpt.edu
} 


\section{Introduction}

By the closing months of 2010, direct Palestinian-Israeli violence had waned. Palestinians committed no suicidal act of political violence (until the bombing in March 2010 the last confirmed act took place in late 2008); there were only four shooting incidences in the occupied West Bank; Israeli night raids were down; and the Israeli army made fewer army incursions into Palestinian population centers and made more frequent use of summons for interrogation, rather than immediately detaining Palestinians. "Israel-Palestinian [direct] violence was relatively low" ${ }^{\prime 3}$ during this period because: 1) levels of direct violence were so grotesquely high in years previous, 2) the structural violence of the Palestinian-Israeli relationship is so totalizing in the case of the former, particularly in the besieged Gaza Strip, and 3) the Obama administration had invested considerable time and energy, pressuring the Palestinians and incentivizing Israel, to facilitate talks between the parties.

My argument is that the efforts made by the Obama administration will not produce Palestinian-Israeli peace. Moreover, the initiatives of the Obama administration will increase direct Palestinian-Israeli violence and exacerbate the structural violence to which Palestinians are subject. The Obama administration's efforts, like the Oslo Process (1993-2000) and postOslo initiatives - the "Gaza-Bethlehem First" initiative, the Quartet's Roadmap, the Geneva Accord, Sharon's Disengagement Plan and the Annapolis Conference - before them, are articulations of the discourse of Palestinian-Israeli relations, and the performance of this discourse produces violence. Despite the obvious differences between the initiatives, the Geneva Accord was "a private Israeli-Palestinian "civil society' peace initiative," Sharon's Disengagement Plan was executed in close coordination with the U.S., Obama has encouraged both direct and proximity talks between Israel and the Palestinians, they are all products of and reproduce the analytics and practices of the discourse. The Obama's administration's efforts, being only the latest in a long line of discursive reproductions, cannot reasonably be expected to realize a radically different outcome than their predecessors. In fact, so long as roadmaps, accords, conferences and talks continue to be produced in accordance with this discourse the Palestinian-Israeli relationship will be violent. Not only will Obama's efforts fail to produce peace, as have all their post-Oslo predecessors, they will increase the highly unequal levels of Palestinian-Israeli violence.

I develop my argument in four stages. First, I briefly explain my Foucault-inspired analytical framework. Specifically, I contrast discourse analysis with positivistic assumptions regarding the world, knowledge production and truth and identify the insights this framework produces when applied to Palestinian-Israeli relations. Second, I describe and historicize (the discourse of) Palestinian-Israeli relations. I identify the three persistent practices and six analytics, three systematic silences and three rules of formation, that constitute the discourse of Palestinian-Israeli relations. Included among these practices and analytics are: Israel's settlement enterprise; a silence pertaining to the territorial maximization inherent to Zionism; and a rule requiring that the Palestinian-Israeli relationship be represented as symmetrical or that Israel be represented as the victim in the relationship. Also in this stage I review notable statements of the discourse of Palestinian-Israeli relations, the Allon and Begin Plans for example, as well as the Oslo Process. Third, I demonstrate the manner in which all recent Palestinian-Israeli initiatives institutionalized and re-articulated these unconscious rules and

\footnotetext{
${ }^{2}$ Esposito, Michele K.: "Quarterly Update on Conflict and Diplomacy", Journal of Palestine Studies, Vol. 40, No. 2 (Winter 2011), pp 133-134.

${ }^{3}$ Ibid., p. 133 .

4 “The Geneva Accord,” Journal of Palestine Studies, Vol. 33, No. 2 (January 2004), p. 81.
} 
practices. For example, the Geneva Accord was silent regarding Zionism's territorial desideratum and posited Israel as the victim of Palestinian/Arab aggression. Fourth and finally, I argue that previous articulations of this discourse did not produce peace between Palestinians and Israel and, furthermore, that these more recent initiatives, too, have, or will, produce Palestinian-Israeli violence. The same analytics, the same practices, the same institutions - the same truth of Palestinian-Israeli relations - will not produce different effects of power in this relationship. Peace requires a changing of the discourse, not yet another (re)production of the discourse, this time under the aegis of Obama's talks.

\section{Analytical Framework}

Discourse analysis is a post-positivistic framework. As such, it rejects three important empiricist assumptions. First, discourse analysis is not rooted in epistemic realism, or "the view that there is an external world, the existence and meaning of which is independent of anything the observer does." Second, analyses of discourses hold that the world is only ever described in and by language that presupposes and by observers who never ascend to some Archimedean point outside their time, space, culture and politics. ${ }^{6}$ Third and finally, discourse analysis abnegates "the correspondence theory of truth: that the observer can capture the facts of the world in statements that are true if they correspond to the facts and false if they do not." 7

In place of these positivistic notions - that there is a real world out there beyond the knowing subject, that the knowing subject can use language as a transparent means of describing that really existing world, and can do so objectively, and that truth is a quality of conforming with fact - discourse analysis, for my purposes here, understands the world as made, knowledge of the made world to be subjectless and truth to be a set of rules of knowledge production.

First, for discourse analysis the world has no pre-existing meaning. Whatever meaning the world has, and it is malleable, is linguistically constructed and socially constituted. This, in turn, means that the meaning ascribed the world is implicated in and made by power relations. Following Nietzsche, "there is no original signified." " "L[]anguage itself [is] an expression of power," 9 and the words and interpretations that construct the world are the inventions and impositions of ruling classes. There is no world "at the bottom" with an essential meaning. The world is the most recently imposed, by power, interpretation resting on layers of previously imposed and subsequently superseded interpretations.

Second, discourse analysis rejects the author principle; or, as Dreyfus and Rabinow explain it, is a "method purged of all anthropologism." hold that knowledge is produced by a sovereign subject, discourse analysis proceeds from the

\footnotetext{
5 Campbell, David: "Poststructuralism," in Dune, Tim; Kurki, Milja and Smith, Steve (eds.) (2007): International Relations Theories: Discipline and Diversity. Oxford, Oxford University Press, p. 208.

${ }^{6}$ Ibid.

${ }^{7}$.Ibid.

${ }^{8}$ Foucault, Michel: "Nietzsche, Freud, Marx", in Faubion, James D. (ed.) (1998): Michel Foucault: Aesthetics, Method and Espistemology, Volume 2. New York, The New Press, p. 276.

${ }^{9}$ Nietzsche, Friedrich Wilhelm and Kaufman, Walter Arnold (1967): On the Genealogy of Morals. New York, Vintage Books, 1967, p. 26.

${ }^{10}$ Dreyfus, Hubert L. and Rabinow, Paul (1983): Michel Foucault: Beyond Structuralism and Hermeneutics. Chicago, University of Chicago Press, p. 53.
} 
premise that there is no sovereign, founding subject of knowledge. ${ }^{11}$ Authors themselves are the products of discourses, and they never articulate statements or texts in isolation but rather always in matrixes of, inter alia, objects, categories, frameworks, practices, legitimate practitioners, institutions, power and extra-textual rules. Individual authors make decisions about specific statements, but the effects of the matrixes in which they write, and of which they are often unconscious, are so overdetermining as to render the idea of a founding subject of knowledge a modern fiction. To quote Foucault: "[I reject what] ... (one might call ... broadly speaking, the phenomenological approach) which gives absolute priority to the observing subject, which attributes a constituent role to an act, which places its own point of view at the origin of all historicity - which, in short, leads to a transcendental consciousness." 12 In place of the phenomenological subject producing truthful knowledge, discourse analysis studies the structure of rules that define what counts as truthful knowledge.

Third, in its rejection of the correspondence theory of truth discourse analysis does not ask what statements are empirically true, but rather how some statements came to be counted as true, and others not. The modalities of truthful knowledge production involve abiding by extra-textual rules. As Foucault explained: "by truth I do not mean 'the ensemble of truths which are to be discovered and accepted', but rather the ensemble of rules according to which the true and false are separated and specific effects of power are attached to the true." ${ }^{\prime 13}$ These rules constitute "a positive unconscious of knowledge;" while "never formulated in their own right" 14 these protocols govern representations and claims made by authors. For discourse analysis, truthful knowledge is knowledge authored, unconsciously, in accordance with these extra-textual rules of inclusion and exclusion, what are also called the "analytics of truth." Truth is not a quality of approximating the real world. It is a game or regime of analytics that authorizes some statements and prohibits or silences others.

Knowledge and power are brought together in discourses. "A discourse is the matrix of extra-textual rules to which the effects of power are attached." ${ }^{15}$ A discourse is secondorder or meta-rule policed knowledge in accordance with which power is exercised (it hardly bears noting here that "truth and falsity have serious social consequences"" ).

Discourses are not somehow limited to the domain of knowledge, however. Discourses are parts of larger fields of practices and institutions. Take, for example, the discourse of madness: in the $18^{\text {th }}$ century a whole new order of concepts was constituted to organize, discipline and ascribe meaning to madness. At the same time, practices surrounding madness changed. Instead of excluding the mad, but permitting them mobility, they were taken in and confined. The change in knowledge producing techniques and practices was also attended by institutional change. The asylum was developed to allow for the study of the mad, and for the production of more truthful knowledge about the mad, and to constrain them. ${ }^{17}$ Or, in the present case: one of the analytics of the discourse of Palestinian-Israeli relations is to

\footnotetext{
${ }^{11}$ Foucault, Michel: Aesthetics of Existence," in Kritzman, Lawrence D. (ed.) (1988): Politics, Philosophy, Culture: Interviews and Other Writings, 1977-1984. New York, Routledge, p. 50.

${ }^{12}$ Foucault, Michel (1994): The Order of Things: Archaeology of the Human Sciences. New York, Vintage Books, p. xiv.

${ }^{13}$ Foucault, Michel: "Truth and Power," in Gordon, Colin (ed.) (1980): Power/Knowledge: Selected Interview and Other Writings, 1972-1977, $1^{\text {st }}$ American ed.. New York, Pantheon Books, p. 132.

${ }^{14}$ Foucault, The Order of Things..., op. cit., p. xi.

${ }^{15}$ McMahon, Sean F. (2010): The Discourse of Palestinian-Israeli Relations: Persistent Analytics and Practices. London, Routledge Press, p. 12.

${ }^{16}$ Dreyfus and Rabinow, op. cit., p. 48.

${ }^{17}$ Foucault, Michel (1988): Madness and Civilization: A History of Insanity in the Age of Reason. New York, Vintage Books.
} 
represent Israel as the victim in the Palestinian-Israeli relationship or posit the relationship as symmetrical. A practice that has attended this discursive rule is the encouragement of confidence-building measures. The discourse was institutionalized in Article XVI of the 1995 Oslo II Agreement. Ultimately, "discourses are performative"18 and performed. They constitute the world about which they make truthful knowledge claims, are practically realized and are institutionalized.

As a post-positivistic approach, discourse analysis escapes the confines imposed by the dominant foundational interpretations of Palestinian-Israeli relations. The analysis is not bound by the state-centrism, ahistoricism and balance of power doctrine of Realism which denies the centrality of the local dispute in Palestine in constructing a regional "Arab-Israeli conflict." 19 Concomitantly, because for this framework "there is no subject, individual or collective, moving history," 20 discourse analysis moves past Liberal interpretations that mistakenly contend that a change in leadership, either a more dovish Labor prime minister in Israel, a more compromising president of the Palestinian National Authority, or a more engaged American president, will end Palestinian-Israeli violence. ${ }^{21}$ By interrogating Palestinian-Israeli relations, and particularly Obama's recent interventions, with notions of the linguistic and social construction of the world, the subjectless of knowledge and the rule governed nature of truth, combined with fields of practically exercised and institutionalized power, discourse analysis produces, inter alia, a novel means of reconciling the two communities.

\section{Describing and Historicizing (the Discourse of) Palestinian-Israeli Relations}

In this section I describe and historicize (the discourse of) Palestinian-Israeli relations. As I have demonstrated elsewhere, the discourse of Palestinian-Israeli relations is comprised of six persistent analytics, variously obeyed and institutionalized, and three persistent practices. ${ }^{22}$ The analytics of the discourse are evenly divided between silences and rules of formation. The discursive silences involve: 1) the Zionist idea of transfer, 2) the drive to maximize territory inherent in Zionism, and 3) Zionism denial of the existence of the Palestinian nation and this nation's right to self-determination. The rules of formation require: 1) Palestinians/Arabs be represented as intransigent and Israel as peace-seeking and compromising, 2) Israel be represented as the victim in the Palestinian-Israeli relationship, or the relationship be represented as symmetrical and 3) assuming that Zionism/Israel would permit the establishment of a sovereign Palestinian state in mandate Palestine. These silences and rules have long governed how Palestinian-Israeli relations are talked about and performed. More recently, they were institutionalized across the range of the Oslo Agreements, from the original 1993 Declaration of Principles on Interim Self-Government Arrangements (DOPOISGA) to the Clinton proposals of 2000.

\footnotetext{
${ }^{18}$ Campbell, op.cit., p. 216.

${ }^{19}$ Pappe, Ilan (1992): The Making of the Arab-Israeli Conflict 1947-1951. London, I.B. Tauris, p. x.

${ }^{20}$ Dreyfus and Rabinow, op. cit., p. 109.

${ }^{21}$ See Shlaim, Avi: "The Rise and Fall of the Oslo Peace Process" in Fawcett, Louise (ed.): International Relations of the Middle East. Oxford, Oxford University Press, pp. 254-271.

${ }^{22}$ See McMahon, op. cit.
} 
The three persistent practices of the discourse afford an opportunity to historicize Palestinian-Israeli relations and, as a result, are surveyed first. My description of the analytics of the discourse then follows.

\subsection{Three Persistent Practices}

Because Israel is the more powerful party in the Palestinian-Israeli relationship, the three persistent practices are Israeli: 1) settlement, 2) producing "acceptable" Palestinian interlocutors and 3) proffering initiatives ostensibly aimed at ending Israel's now 43-year occupation of the West Bank and Gaza Strip.

Immediately after conquering the West Bank and Gaza Strip in 1967, Israel started building institutions and infrastructure in, and transferring its civilian population to the territory. Nine years after the occupation of the West Bank and Gaza Strip, the Israeli settler population was 10,531. Another nine years after that in 1985 it was 149,900 . By 1990, there were 216,900 settlers; by 2000, 371,904; and by 2008, 488,471.23 Israel's relentless expropriation of Palestinian land and transfer of its Jewish population is a practice that has persisted through changes in Israeli governments (Labor and Likud governments do not disagree in principle on settlement, they execute the practice differently with Labor doing it, as former Labor Minister of Defense Ben-Eliezer noted, "quietly"24), American administrations, Palestinian presidents, two intifadas, a half dozen regional wars and one "peace" process. On this last point, it is important to note that the more frequently, vocally and hopefully Palestinian-Israeli "peace" is talked about, the more and faster Israeli settlements are built.

The second persistent practice involves the production of Palestinian interlocutors acceptable to Israel. Beginning in 1967, Israel devised a number of different mechanisms to try and produce Palestinians Israel could accept as quislings and facilitators of the Israeli occupation of the West Bank and Gaza Strip. From 1967 to 1974 Israel employed the notable systems. This system followed the classical model of colonial administration. Notable individuals and families in villages such as Hebron and Jericho functioned, in exchange for favors from Israel's military administration, as intermediaries between the administration and occupied Palestinians. The notables also served to "moderate" communal expectations and demands. When the notables system lost its efficacy, the Israeli military administration offered Palestinians elections in 1976. From the Israeli perspective, the elections were a failure. While they were relatively free and fair, particularly given they were conducted under an illegal military occupation, they produced mayors supportive of the P.L.O. (Palestine Liberation Organization), and hence "unacceptable" to Israel. In 1981, Israel then established the Village Leagues system. The Village Leagues were an attempt by the Israeli military authority to undermine indigenous Palestinian civil society organizations. While the Leagues were well financed by the Israeli military authority, the indigenous civil society organizations were harassed by the Israeli military in an attempt to drive Palestinians to the Leagues, thereby investing them with legitimacy. Like the mechanisms that came before them, the Village Leagues also failed to produce Palestinian interlocutors Israel found "acceptable" as instruments in the Occupied Territories. Throughout the 1980s, Israel modified its means, but not the end of producing "acceptable" interlocutors. Instead of producing an alternative to

\footnotetext{
23 Foundation for Middle East Peace: "Comprehensive Settlement Population 1972-2009", at http://www.fmep.org/settlement_info/settlement-info-and-tables/stats-data/comprehensive-settlementpopulation-1972-2006.

${ }^{24}$ Chomsky, Noam: "Introduction," in Carey, Roane (ed.): The New Intifada: Resisting Israel's Apartheid. London, Verso Books, p. 16.
} 
P.L.O. leadership Israel found more acceptable, as the system of notables and Village Leagues were intended to do, the occupying regime took to supporting Islamic militants in the West Bank and Gaza Strip as a means of weakening, and thereby moderating, the P.L.O. The success of this strategy was made abundantly clear in 1993 with the start of the Oslo Process. One of the primary reasons the P.L.O. initiated the Oslo Process was because while it was exiled in Tunis it was losing its political primacy in the Occupied Territories to the resident and ascendant HAMAS. Israel started the Oslo Process with the P.L.O. not because the P.L.O. was politically strong, but because it was weak (after the 1991 Gulf War the P.L.O. was denied monetary support from Gulf states such as Saudi Arabia and Kuwait as well as foreign remittances from Palestinians employed in those rentier economies). This weakness, in turn, meant that the P.L.O. was willing to abandon a number of long-held political positions and consequently became "acceptable" to Israel. The P.L.O. remained an "acceptable" interlocutor until 2000 when Arafat refused to compromise further at the Camp David negotiations. This was never clearer than in the executions of Israel's "Operation Field of Thorns" in 2000 and "Operation Defensive Shield" in 2002 through which Israel destroyed the apparatuses of the Palestinian National Authority (P.N.A.) in the Occupied Territories. ${ }^{25}$

This second persistent practice was most recently performed in 2006 when Israel rejected the legitimate election of HAMAS in the Palestinian legislative elections. Instead of engage the representatives chosen by Palestinians, Israel deemed the Petainist Abbas and Fayyad "acceptable" interlocutors precisely because they could not effectively challenge Israeli policy. For decades Israel used a number of different mechanisms to try and produce interlocutors it deemed "acceptable" because they were not the secular, nationalist P.L.O. Since 1993, and particularly in the last half decade, the P.L.O. has been, because of its weakened state and willingness to serve as Israel's security guarantor and realize Israeli designs in the West Bank and Gaza Strip, Israel's "acceptable" interlocutor. The "acceptable" interlocutor may change - it can be a notable, an elected West Bank Mayor, Mustafa Dudin of the Village Leagues, even the P.L.O. - but Israel's long-standing practice of trying to produce that interlocutor continues as long as Israel remains dominant in the Palestinian-Israeli relationship.

The third persistence practice of the discourse of Palestinian-Israeli relations involves Israel proffering initiatives ostensibly intended to end the occupation of the West Bank and Gaza Strip. In the post-1967 period this practice has been realized in the Allon Plan, Begin's Autonomy Plan, Shamir's Four Point Plan, the Oslo Agreements and, most recently, Ehud Olmert's proposals of September 2008. All of these initiatives sought to reconcile Israel's territorial desires in the occupied West Bank and Gaza Strip with its racist, demographic concerns. Phrased differently, all of these initiatives have been attempts to increase the space over which Israel exercises sovereignty without increasing, and ideally reducing, the number of Palestinians in that space. Always this territorial expansionism/demographic reductionism has been done under the cover of "peace."

The Allon Plan was named after the head of Israel's Ministerial Committee on Settlements, Yigal Allon. The plan was prepared only months after the conclusion of the 1967 war. The Allon Plan "proposed the annexation of Judea to Israel and the granting of a semiautonomous status to Samaria, the northern half of the West Bank."26 It also recommended

\footnotetext{
${ }^{25}$ For descriptions and analyses of the two operations see Cordesman, Anthony (2000): Peace and War: Israel Versus the Palestinians. Washington D.C., Center for Strategic and International Studies. See also Reinhart, Tanya (2002): Israel/Palestine: How to End the War of 1948. New York, Seven Stories Press.

${ }^{26}$ Shlaim, Avi (2000): The Iron Wall: Israel and the Arab World. New York, W.W. Norton, p. 256.
} 
that Israel incorporate "a strip of land ten to fifteen kilometers wide along the Jordan River; most of the Judean desert along the Dead Sea; and a substantial area around Greater Jerusalem." 27 To this end, the Allon Plan called for Israeli Jewish settlement in the Jordan Valley and the Etzion Bloc east of Jerusalem, spaces relatively sparsely populated by Palestinians.

The Allon Plan sought to annex as much territory to Israel as possible containing as few Palestinians as possible. It amounted to one balancing of the territory-population equation. The Allon Plan was abandonded in 1977 when the Likud won its first election in Israel, and subsequently the Begin Autonomy Plan was offered as another way to balance the territory-population equation.

The Begin Autonomy Plan sought to replace Israel's military administration of the West Bank and Gaza Strip with Palestinian administrative autonomy. ${ }^{28}$ "This autonomy was to be expressed through an elected administrative council with responsibilities for affairs such as education, transportation, health, labor, finance, and construction and housing. Palestinians would vote for this council and would constitute its membership." ${ }^{29}$ Ultimately, Begin's plan meant that Israel would maintain sovereignty over all the territory it conquered in 1967 while divesting itself of responsibility for the people who lived on the territory. Phrased differently, the Begin Autonomy Plan granted "autonomy for the people [Palestinians], not for the land.",30

Both the Allon and Begin Plans were attempts to reconcile Israel's territorial desideratum with its demographic concerns. The former sought to retain the majority of the conquered territory while transferring authority over and responsibility for the majority of the population to local Palestinian leaders or Jordan. The latter sought to control all of the territory while transferring authority over and responsibility for all the population to an administrative council. ${ }^{31}$ Both plans envisioned only a limited Palestinian autonomy. Neither countenanced a sovereign Palestinian state in Palestine.

Substantively, Shamir's Four Point Plan was almost identical to his predecessor's autonomy plan. The difference amounted to Shamir offering the occupied Palestinians elections by which they would produce "appropriate" representatives who would then negotiate with Israel. Shamir was clear: "[t]he aim of the elections is to bring about the establishment of a delegation that will participate in negotiations on an interim settlement, in which a self-governing administration will be set up." ${ }^{, 32}$ The Shamir Plan brought together the second and third persistent practices - producing "acceptable" interlocutors with whom Israel could negotiate to ostensibly end its occupation of the West Bank and Gaza Strip. Ultimately, the Allon Plan, the Begin Autonomy Plan and Shamir's Four Point Plan had four aspects in common: "1) denial of the Palestinian right to national self-determination through autonomy schemes; 2) annexation of large tracts of land by the Israeli state in the form of settlements; 3) a transfer of responsibility for the Palestinians in the West Bank and Gaza Strip; and 4) continued Israeli sovereignty over large portions or all of the territories." 33

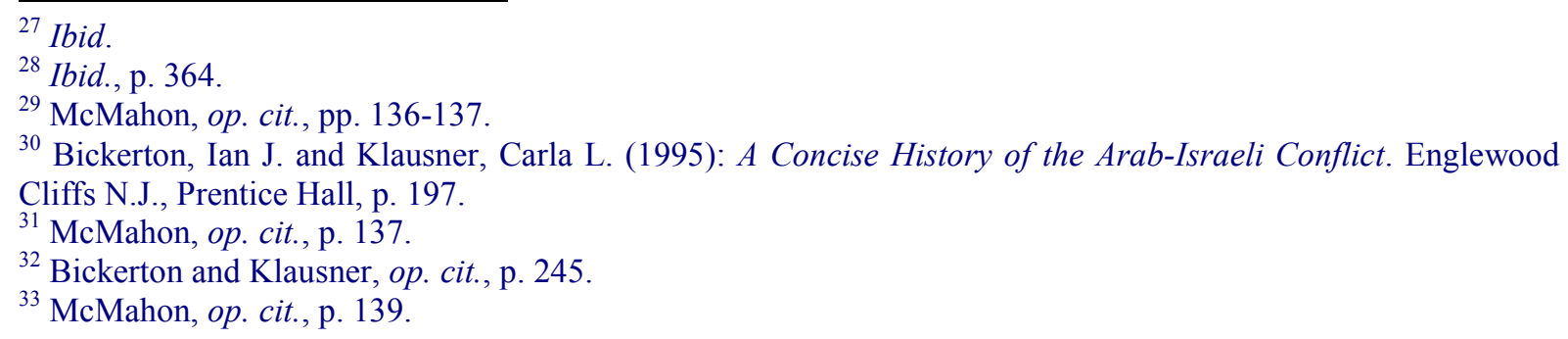


This practice was finally successfully realized from Israel's perspective in 1993 when the P.L.O. agreed to participate in the Oslo Process. A number of the agreements constituting the Oslo Process were verbatim restatements of some of these earlier Israeli initiatives. The DOPOISGA saw a transferring of the Gaza Strip and the West Bank town of Jericho to the Palestinian National Authority because they were highly populated by Palestinians. This was the realization of the Allon Plan. Through the agreement Israel retained exclusive purview over security. This was an aspect of the Begin Autonomy Plan. Finally, the agreement established a "self-governing administration" for the Palestinians. This was the realization of the Shamir Plan.

The same pattern obtains throughout all the subsequent Oslo Agreements. The Early Empowerment Agreement again realized aspects of the Shamir Plan. The Protocol on Further Transfer of Powers and Responsibilities further institutionalized the Begin Plan. And the Oslo II Agreement realized further the tenets of the Allon Plan.

\subsection{Three Silences}

The first discursive silence involves the Zionist practice of transfer. As Masalha explains "transfer" is a Zionist "euphemism denoting the organized removal of the indigenous population of Palestine to neighboring countries." 34 Furthermore, "the idea of transfer is as old as the early Zionist colonies in Palestine and the rise of political Zionism,"35 and that "[v]irtually every member of the Zionist pantheon of founding fathers and important leaders [including most notably Ben-Gurion and Jabotinsky] supported it." ${ }^{36}$ Transfer was essential to Zionism's goal of creating a demographically homogenous state in Palestine. It became a prerequisite for partition of Palestine. "[P] artition was unacceptable [to the Zionists] without transfer." $" 37$

Despite being a central plank of Zionism, the idea and practice of transfer has been silenced by the discourse. Authors such as Jon and David Kimche and Benny Morris have produced truthful knowledge of Palestinian-Israeli relations by denying Zionist and Israeli responsibility for razing 350 villages and creating 750,000 Palestinians refugees in $1948 .{ }^{38}$ In such instances, authors assign responsibility for the ethnic cleansing of Palestine, rather incredulously, to Palestinians/Arabs. In Both Sides of the Hill: Britain and the Palestine War, for example, the Kimches propound what has become known as the "order theory." This amounts to the claim that

[t]he flight of the Palestinians from the country, both before and after the establishment of the state of Israel, came in response to a call by the Arab leadership to leave temporarily, in order to return with the victorious Arab armies. They fled despite the efforts of the Jewish leadership to persuade them to stay. ${ }^{39}$

According to the Kimches, Palestinians were not driven from Palestine, but rather left on instructions of Arab leaders to return victorious at some later time. In 1948 and After: Israel

\footnotetext{
${ }^{34}$ Masalha, Nur (1992): Expulsion of the Palestinians: The Concept of "Transfer" in Zionist Political Thought 1882-1948. Washington D.C., Institute for Palestine Studies, p. 1.

${ }^{35}$ Ibid.

${ }^{36}$ Ibid., p. 2.

${ }^{37}$ Ibid., p. 68.

${ }^{38}$ Ibid., p. 175.

${ }^{39}$ Flapan, Simha (1987): The Birth of Israel: Myths and Realities. New York, Pantheon Books, p. 81.
} 
and the Palestinians and The Birth of the Palestinian Refugee Problem Revisited Morris dismisses the "order theory." This does not mean, however, that he violates this first discursive silence. Morris contends that the Palestinian refugees were not intentionally ethnically cleansed by Israel, but were a vicissitude of a war started by the Arab states against Israel. According to Finkelstein, "the upshot of Morris's argument is that the Arabs - who, after all, were the aggressors, must bear the brunt of political (if not moral) responsibility for the birth of the Palestinian refugee problem."40 It is not without a good deal of irony that Finkelstein asks rhetorically: "[w] hat is this if not the official Zionism's 'astonishing' flight of Palestine's Arabs now graced with Morris's imprimatur?"41 Authors producing truthful knowledge of Palestinian-Israeli relations do not talk about Zionism/Israel ethnically cleansing Palestine in 1948, instead they assign responsibility for the creation of the Palestinian refugees to Palestinians and/or Arabs.

Zionism performed the idea of transfer through Plan Dalet (Plan D). Plan D "aimed at the de-Arabization of all areas under Zionist control [according to the United Nations' (U.N.) 1947 partition plan]."42 Plan D was a spectacular success given that 80 per cent of the Palestinian population was expelled, yet to return. The idea and practice of transfer did not end with the conclusion of Plan D and the establishment of the state of Israel in 1948. Transfer is realized every day Israel denies Palestinians the internationally recognized right of return. Moreover, the idea and practice were extended when Israel occupied the West Bank and Gaza Strip in 1967. According to Ilan Pappe, Israel continued to execute" a policy of slow transfer [from these spaces]." contemporary period, except now instead of doing it under cover of war, it is done incrementally and largely administratively: Israel employs "exile and deportation; revoking of residency rights; economic impoverishment; land expropriation; house demolitions and other means of making like in the occupied territories so unbearable that it will induce 'voluntary' Palestinian emigration." ${ }^{, 4}$ In general, the terrorizing of Palestinians throughout the West Bank is the contemporary means of performing transfer. This is done because "[s]chemes of 'transfer' have become a common and acceptable part of Israeli political discourse." 45 The practice of transfer has persisted because the idea has persistently received support from Israeli Jews.

The discursive silence involving transfer was institutionalized in, for example, the original 1993 DOPOISGA. While the DOPOISGA, as well as all of the Oslo agreements, referenced "refugees" (in denationalized and abstract form), it did not recognize that they were forcibly expelled from Palestine. The DOPOISGA is ahistorical regarding the emergence of the refugees and consequently does not acknowledge that Zionism/Israel bears responsibility for creating them.

The second silence involves the territorial maximization inherent in Zionism. "From beginning to end, Zionism was a conquest movement." 46 This is not how Zionism or its

\footnotetext{
${ }^{40}$ Finkelstein, Norman (2003): Image and Reality of the Israel-Palestine Conflict. New York, Verso Books, p. 75.

${ }^{41}$ Ibid., p. 87.

${ }^{42}$ Cooke, Hedley V.; Kimche, Jon; Childers, Erskine B.; Khalidi, Walid; Atiyah, Edward and Cairns, David: “Appendix E: The Spectator Correspondence," Journal of Palestine Studies 18, No. 1, Special Issue: Palestine 1948 (1988), p. 67.

${ }^{43}$ Pappe, Ilan: "Break the Mirror Now," in Carey, Roane and Shainin, Jonathan (eds.) (2002): The Other Israel: Voices of Refusal and Dissent. New York, The New Press, p. 110.

${ }^{44}$ Halper, Jeff: "The Key to Peace: Dismantling the Matrix of Control," in Carey and Shainin, op. cit., p. 26.

45 Ibid.

${ }^{46}$ Finkelstein, op. cit., p. 108.
} 
institutional expression in Israel have been represented in the dominant literature. Truthful knowledge of Palestinian-Israeli relations is silent on the fact that "Zionists, one and all, were territorial maximalists." 47 Zionism performed territorial maximization in, inter alia, the wars of 1948 and 1967. Plan D was the instrument of territorial aggrandizement in 1948. According to the plan's introduction

[t]he objective of this plan [was] to gain control of the areas of the Hebrew state and defend its borders. It also aim[ed] at gaining control of the areas of Jewish settlement and concentration which are located outside the borders [of the Hebrew state] against regular, semi-regular, and small forces operating from bases outside or inside the state. ${ }^{48}$

Plan D was not only intended to ethnically cleanse Palestinians from the territory allotted the Jewish state by the U.N. partition plan, it was also designed to expand the space of the Jewish state. It was offensive in nature. So, too, was Israel's war of choice in 1967. According to no less than former Israeli Prime Minister Menachem Begin: "we had a choice. The Egyptian army concentrations in the Sinai approaches do not prove that Nasser was really about to attack us. We must be honest with ourselves. We decided to attack him." "A9 Authors such as Michael Oren and Michael Walzer do not countenance the idea that Israel's wars have, overwhelmingly, been wars of choice conducted with the goal of seizing additional territory. Rather incredulously, Walzer, for example, "list[s] Israel's preemptive strike as one of a handful of unambiguous cases of self-defense in the twentieth century." 50 Whether the knowledge produced involves the war of 1948, 1956, 1967 or 1982, the discourse prohibits inclusion of Zionism's territorial desideratum in the representation.

This discursive silence, too, was institutionalized in the DOPOISGA; again as a result of ahistoricism. Nowhere in the Oslo Process is there an "explanation for how Israeli military forces came to occupy their positions in the West Bank and Gaza Strip from which they were to withdraw in accordance with the DOPOISGA, or even the reason for the DOPISGA." 51 The extent to which the Oslo Process is historicized is its being premised exclusively on U.N. Security Council Resolutions 242 and 338. While the English text of Resolution 242 asserts "the inadmissibility of the acquisition of territory by war," it also "provides that peace 'should' (not 'must') include the withdrawal of Israeli forces 'from territories occupied in the recent conflict,' not from the territories occupied' in that conflict." 52 There is no recognition, in either Resolution 242 and by extension the Oslo Process, that Israel came to occupy the territories through an aggressive war of choice. Furthermore, the absence of the definite article has allowed Israel and the Unites States to contend that Israel can evacuate only some of the territory seized in 1967 and still be abiding by international law. The Oslo Process was narrowly grounded on two U.N. Security Council Resolutions, rather than in the more robust international consensus that holds that Israel must withdraw from all the territories occupied

\footnotetext{
47 Shafir, Gershon: "Zionism and colonialism: a comparative approach," in Pappe, Ilan (ed.) (1999): The Israel/Palestine Question: Rewriting Histories. New York, Routledge Press, p. 90.

${ }^{48}$ Khalidi, Walid: "Plan Dalet: Master Plan for the Conquest of Palestine," Journal of Palestine Studies, Vol. 18, No. 1, Special Issue: Palestine 1948 (1988), p. 24. My emphasis added.

${ }^{49}$ Norman Finkelstein, Image and Reality of the Israel-Palestine Conflict (New York: Verso Books, 2003), 134135. My emphasis added.

${ }^{50}$ Finkelstein, op.cit., p. 140.

${ }^{51}$ McMahon, op.cit., p. 84.

52 Watson, Geoffrey R. (2000): The Oslo Accords: International Law and the Israeli-Palestinian Peace Agreements. Oxford, Oxford University Press, p. 31.
} 
in 1967, including all of the West Bank and Gaza Strip. The Oslo Process reduced most international law on the question of Palestine to irrelevancy, institutionalized negotiated withdrawals and redeployments from portions of and around the West Bank and Gaza Strip and had the effect of constituting the territories as disputed rather than occupied. ${ }^{53}$ As a result, the Oslo Process became a series of negotiations involving Israeli redeployments. The Cairo Agreement institutionalized the negotiations involving Israeli withdraw from the Gaza Strip and Jericho. The Israeli-Palestinian Interim Agreement redeployed the Israeli military through Areas A, B and C. The Hebron Protocol institutionalized Israel's redeployment in Hebron. Ultimately, basing the Oslo Process exclusively on Resolutions 242 and 338 had the effect of dehistoricizing, how, exactly, Israel came to occupy Palestinians in the West Bank and the Gaza Strip; of silencing the fact that Zionism was/is a conquest movement that had long coveted the spaces it came to occupy through the 1967 war it chose to wage.

The third and final discursive silence involves Zionism's/Israel's denial of the Palestinian nation and that nation's right to self-determination. Said identified this analytic: "Zionism first refused to acknowledge the existence of native inhabitants in Palestine, and when it did, it recognized only native inhabitants with no political or national rights. ${ }^{, 54}$ Proof of this view lies in statements made by notable Zionists; Weizmann: "there is a country which happens to be called Palestine, a country without a people, and, on the other hand, there exists the Jewish people, and it has no country;", Jewish and Palestinian nationalism because the Jewish nation is not in Palestine and the Palestinians are not a nation;" "56 and Meir: "[i]t is not as though there was a Palestinian people in Palestine considering itself a Palestinian people and we came and threw them out and took their country away from them. They did not exist." ${ }^{, 57}$ Again, according to Said, Zionism's imperial epistemology was part of the much larger and very powerful discourse of Orientalism. ${ }^{58}$ Both discourses, the meta- and the meso-discourse denied distinctness, of culture, history, place of belonging, to their objects. The meta-discourse produced truthful knowledge with an ontology of the "Orient." The meso-discourse produced truthful knowledge with an ontology of the "Arab-Israeli conflict."

Zionism's/Israel's denial of Palestinian nationhood and right to national selfdetermination, and the discursive silence surrounding it, was institutionalized in the 1978 Camp David Frameworks for Peace and again during the negotiations leading up to the 1993 DOPOISGA. At first blush, the Camp David Agreements seem to violate this practice. They talk of "representatives of the Palestinian people" and "Palestinians from the West Bank and Gaza Strip.” However, as Shibley Telhami explains:

[a]lthough the term "Palestinian people" is employed in the text of the Camp David Accords, a letter from President Carter to Prime Minister Begin, written at the latter's urging and appended to the accords, stated that Carter acknowledged that "in each paragraph of the

\footnotetext{
${ }^{53}$ Adoni, Lamis: "Redefining Oslo: Negotiating the Hebron Protocol," Journal of Palestine Studies, Vol. 26, No. 3 (1997), p. 24.

${ }^{54}$ Said, Edward W. (1992): The Question of Palestine. New York, Vintage Books, pp. 230-231.

${ }_{55}^{55}$ Masalha, op.cit., pp. 5-6.

${ }^{56}$ Ibid., p. 19.

${ }^{57}$ Shlaim, op.cit., p. 311.

${ }^{58}$ Said, op. cit., pp. xl and 15-37.
} 
agreed framework document, the expressions 'Palestinians' or 'Palestinian People' are being and will be construed and understood by you as 'Palestinian Arabs'."59

In Camp David, Palestinians were denied their distinctness, their separateness and subsumed under the larger Arab nation. In the lead up to the Oslo Process this practice was extended and Palestinians were denied the rights attending nationhood. During a July 1993 negotiating session in Oslo both Palestinians and Israeli negotiators recognized that the DOPOISGA perpetuated the Zionist practice of denying Palestinians national rights. Palestinian negotiator Ahmed Qurie objected to an Israeli position with the observation: "[y]ou want full responsibility for security, but you won't recognize our national rights." 60 Israeli negotiator Uri Savir retorted: "[w]e have been fighting for a century. We're just now beginning to build mutual trust. We will not recognize your national rights because that means assenting to a state." ${ }^{61}$ This denial was extended again in the supposedly "mutual" recognitions made in the letters Arafat and Rabin exchanged in 1993. Arafat fully recognized Israel's right to exist in peace in security. Rabin recognized Palestinians only in highly rarefied forms, and then made no mention of rights.

\subsection{Three Rules of Formation}

Just as there are three silences that must be obeyed to produce truthful knowledge of Palestinian-Israeli relations, there are also three rules of formation that must be followed.

These rules are more easily evidenced than are the silences as it is easier to prove a presence than an absence.

The first rule of formation governing the discourse of Palestinian-Israeli relations is to represent Palestinians/Arabs as intransigent and Israel as compromising and peace-seeking. Friedman's From Beirut to Jerusalem was produced in accordance with this analytic:

[t]he Zionists then led by David Ben-Gurion, accepted this partition plan [the U.N. plan of 1947], even though they had always dreamed of controlling all of western Palestine and Jerusalem. The Palestinians Arabs and the surrounding Arab states rejected the partition proposal ... on May 14, 1948, the Zionists declared their own state, and the next day the Palestinians, aided by the armies of Jordan, Egypt, Syria, Lebanon, Saudi Arabia and Iraq launched a war to prevent Jewish independence. ${ }^{62}$

So, too, was moral theorist Walzer's "The Green Line": "haven't the Arabs been at war with Israel for 40 years now, always refusing (Egypt the only exception) to accept Israeli statehood?;"63 and ominously "[i]t is still not clear that the leadership of the PLO really wants

\footnotetext{
${ }^{59}$ Telhami, Shibley: "Israeli Foreign Policy: A Realist Ideal-Type or a Breed of Its Own?" in Barnett, Michael N. (ed.) (1996): Israel in Comparative Perspective: Challenging the Conventional Wisdom, SUNY Series in Israel Studies. Albany, State University of New York Press, p. 39.

${ }^{60}$ Savir, Uri (1998): The Process: 1,100 Days that Changed the Middle East. New York, Random House, p. 46.

My emphasis added.

${ }^{61}$ Savir, ibid., pp. 46-47. My emphasis added.

${ }^{62}$ Friedman, Thomas L. (1989): From Beirut to Jerusalem. New York, Farrar, Straus \& Giroux, pp. 14-15.

${ }^{63}$ Walzer, Michael: “The Green Line,” New Republic, Vol. 199, No. 10 (5 September 1988), p. 23.
} 
a West Bank and Gazan ministate: they have missed so many opportunities to move toward that goal that one cannot help wondering whether they don't still have other goals in mind.",64 Even more recent, ostensibly critical texts, such as Lewis' introduction to The Other Israel: Voices of Refusal and Dissent, represent Palestinians/Arabs as intransigent rejectionists: "[f]rom the day of its birth as a state in 1948 Israel had to struggle for acceptance. The Arab world refused to recognize the state or even, for a long time, to call it by its name." 65 The most obvious articulation of this analytic is Ross' The Missing Peace: the Inside Story of the Fight for Middle East Peace. Variously Ross speaks of the "the deep-seated desire for peace in Israel" 66 and opines that "[t]he President [Clinton] had made his best effort, and now so had Barak. Arafat has said no to everything." ${ }^{\circ 7}$ The common practice of blaming Arafat specifically for the collapse the Oslo Process is the hyper-individualization, or personification of this analytic. The clearest indication that a statement has been articulated in accordance with this rule is the invocation of the language of "Israeli concessions."

The first rule of formation was institutionalized early on in the Palestinian police force established by the DOPOISGA and was subsequently performed in, among other places, the Clinton Parameters of 2000. The Palestinian police force was constituted by Article VIII of the DOPOISGA. The "strong police force" was then twice reaffirmed in the Oslo II agreement. The Palestinian security services were a guarantor of Israeli, rather than Palestinian, security. According to Prime Minister Rabin, the Palestinian security services functioned "with Israel's knowledge, and in cooperation with Israel's security forces to safeguard Israel's security interests." ${ }^{\text {"68 }}$ Israel needed a security guarantor because even with peace negotiations that followed from Israeli magnanimity Palestinians could not be counted on to forsake violence. Clinton offered his proposals in December 2000, after the Camp David negotiations with Barak and Arafat, in a last desperate attempt to salvage the Oslo Process. Clinton's parameters were clearly informed by the idea that Palestinians/Arabs are intransigent rejectionists and that Israel is peace-seeking. Clinton's Parameters allowed for the presence of Israeli military units in the Jordan Valley ostensibly as a protection against some imagined "threat from the East"; suggested that Israel have three early-warning stations in the West Bank, again ostensibly to protect against the same imagined threat; and recommended that the Palestinian state be "non-militarized" so as to not constitute a threat to Israel. ${ }^{69}$ It hardly bears mentioning that the encumbrances were all imposed on the Palestinians; no Palestinians units were to be positioned in Israel, Palestine was not to have early-warning stations in Israel, and Israel was most certainly not going to be "non-militarized." Like, the DOPOISGA before it, the concern of the Clinton Parameters was to secure Israel against unremitting Palestinian/Arab hostility.

The second rule of formation is to represent Israel as the victim in the PalestinianIsraeli relationship or represent the relationship as symmetrical. In either case, Palestinians are not represented as victims of Zionism/Israel. Kelman's "Building A Sustainable Peace: The Limits of Pragmatism in the Israeli-Palestinian Negotiations" is an example of truthful knowledge produced in accordance with this analytic. Kelman starts by positing an equality

\footnotetext{
${ }^{64}$ Ibid., p. 24.

${ }^{65}$ Lewis, Anthony: "Introduction," in Carey and Shainin, op. cit., p. 1.

${ }^{66}$ Ross, Dennis (2004): The Missing Peace: the Inside Story of the Fight for Middle East Peace. New York, Farrar, Straus \& Giroux, p. 28.

${ }^{67}$ Ibid., p. 693.

${ }^{68}$ Usher, Graham: “The Politics of Internal Security: The PA's New Intelligence Services," Journal of Palestine Studies, Vol. 25, No. 2 (1996), p. 27.

69 "Doc. D1 President Bill Clinton, Proposals for a Final Settlement," Journal of Palestine Studies, Vol. 30, No. 3 (2001), pp. 171-173.
} 
between the claims of European Jews and Palestinians to Palestine. Then, building on this presumed symmetry, he psychologizes the relationship: the Oslo Process was successful early on because of high levels of trust between the parties, and the process deteriorated when that trust was undermined. ${ }^{70}$ Dehistoricizing the Palestinian-Israeli relationship, particularly by way of making sweeping temporal statements, is a prerequisite for the effective functioning of this analytic.

Bound up with this rule of formation are languages of "partnership" and "cycles of violence." "By claiming that the Palestinians were their "partners' in the peace process, Israel attempted to efface its own history of belligerent occupation and colonization of the West Bank and Gaza Strip." "71 The "cycles of violence" language was performed in the Mitchell Report of 2001. The report deployed the language of "partnership", posited an equality between the competing claims to Palestine, presented its findings in near equal proportion and offered balanced findings. As if the relationship between colonizer and colonized, between a nuclear equipped state and an unarmed indigenous people could ever be equal or balanced. In keeping with this analytic, the report pyschologized the Palestinian-Israeli relationship "[f]ear, hate, anger, and frustration have risen on both sides. The greatest danger of all is that the culture of peace, nurtured over the previous decade, is being shattered. In its place there is a growing sense of futility and despair" 72 - rather than focused on material deprivation suffered by Palestinians, and recommended that the parties implement additional confidencebuilding measures. The second rule of formation requires that truthful knowledge of the Palestinian-Israeli relationship be dehistoricized and depoliticized and, furthermore, that it be psychologized, represented in the language of equality and symmetry and see trust- and confidence-building measures as means of resolving the conflict.

The third rule of formation is to assume that Zionism/Israel would permit the establishment of a sovereign Palestinian state in mandate Palestine. While this analytic has governed the production of truthful knowledge of Palestinian-Israeli relations, the most Zionism/Israel has ever been willing to consider is a contingent Palestinian state that would have to assuage Israeli security concerns in exchange for ersatz sovereignty.

Shlaim and Segev, two notable post-Zionist historians, have authored representative texts through obedience to this rule. Variously says Shlaim: "the Oslo accords, which though not committing Israel to the idea of an independent Palestinian state, pointed in that direction;" "73 and [t]he logic of the Israeli-Palestinian peace process was founded on incremental momentum toward a Palestinian state." 74 Even more forcefully, in his foreword to The Other Israel: Voices of Refusal and Dissent Segev asserts "[Israel] always said it would never agree to the establishment of a Palestinian state. It now [after the start of the Oslo Process] does." 75 Authors writing in accordance with this analytic do so not with the help of the historical record and the reality of Palestinian-Israeli agreements, but despite them.

\footnotetext{
${ }^{70}$ Kelman, Herbert C.: "Building a Sustainable Peace: The Limits of Pragmatism in the Israeli-Palestinian Negotiations," Peace \& Conflict: Journal of Peace Psychology, Vol. 5, no. 2 (1997), pp. 101-115.

${ }^{71}$ Guyatt, Nicholas (1998): The Absence of Peace: Understanding the Israeli-Palestinian Conflict. New York, Zed Books, p. 67.

72 Sharm El-Sheikh Fact-Finding Committee, "Sharm El-Sheikh Fact-Finding Committee Report", U.S. Department of State, at http://www.state.gov/p/nea/rls/rpt/3060.htm.

73 Shlaim, op. cit., p. 575.

${ }^{74}$ Ibid., p. 599.

75 Segev, Tom: "Foreword," in Carey, Roane and Shainin, Jonathan (eds.) (2002): The Other Israel: Voices of Refusal and Dissent, p. xii.
} 
Despite pronouncements to the contrary, Israel's pursuit of Palestinian autonomy and concomitant denial of a Palestinian state was institutionalized in the Oslo Process. This is clear in the title of the originating agreement: Declaration of Principles on Interim SelfGovernment Arrangements. The Oslo Process was about establishing mechanisms by which Palestinians could govern themselves. This was made all the more obvious as the Oslo Process progressed. The DOPOISGA established of a "strong police force." The Early Empowerment Agreement transferred "powers, responsibilities and authority for education and culture, health, social welfare, tourism, direct taxation, and Value Added Tax on local production from the Israeli military government to the PA [Palestinian Authority]."76 The Protocol on Further Transfer of Powers and Responsibilities consigned "the authorities, powers and responsibilities for labor, commerce and industry, gas and petroleum, insurance, postal services, local government and agriculture from the Israeli military government to the PA."77 At the same time, the only explicitly stated aim of the negotiations was to "establish a Palestinian Interim Self-Government Authority." ${ }^{78}$ No reference is made anywhere, in any of the Oslo agreements, to a sovereign Palestinian state. And Palestinians were denied sovereign prerogatives such as the ability to promulgate "primary" legislation, authoritatively police borders encapsulating contiguous territory and make military agreements with other states. In keeping with the Allon and Begin Plans, the Oslo Process institutionalized Palestinian autonomy and denied genuine Palestinian sovereignty. This was made most obvious when the process culminated in the Clinton Parameters of 2000. Clinton proposed as a means of resolving the conflict that Palestinian security "be provided by "international presence that can only be withdrawn by mutual consent';" that Israel maintain "3 EW [Early Warning] facilities in the West Bank;" that Israel have the ability to, in emergencies, deploy through the West Bank; and Palestine be a "non-militarized state."79 A Palestinian state that met Israel's conditions of not controlling its own borders, of being surrounded militarily by Israel, permitting Israel's armed forces to move through it and be non-militarized itself would be a sovereign state in name only. This reality of Palestinian ersatz sovereignty is occulted by authors producing truthful knowledge in accordance with the third rule of formation, particularly those deploying the language of "DOP" - an abbreviated acronym that elides the self-government nature of the agreement.

The discourse of Palestinian-Israeli relations is comprised of three persistent practices, three silences and three rules of formation. Together, the practices and analytics constitute knowledge, are performed and were institutionalized in the Oslo Process. As has been made abundantly clear since late 2000 , this discourse produces considerable direct and structural Palestinian-Israeli violence. The next section surveys the reproduction of the discourse since 2000, a period during which the discourse has been (re-)articulated, performed and institutionalized and 5,365 Palestinians and 542 Israelis have been killed. ${ }^{80}$

\footnotetext{
${ }_{76}^{76}$ McMahon, op. cit., pp. 146-147.

${ }^{77}$ Ibid., p. 147.

${ }^{78}$ Institute for Palestine Studies (Washington, D.C.) (1994): The Palestinian-Israeli Peace Agreement: a Documentary Record, Rev. $2^{\text {nd }}$ ed. Washington D.C., Institute for Palestine Studies, p. 117.

${ }^{79}$ Doc. D1 President Bill Clinton, Proposals for a Final Settlement," Journal of Palestine Studies, Vol. 30, no. 3 (2001), p. 172.

${ }^{80}$ The number of Israeli victims of direct Palestinian-Israel violence includes the period from 2000-2007. Ministry of Foreign Affairs: "Victims of Palestinian Violence and Terrorism since September 2000," Israel Ministry of Foreign Affairs, at http://www.mfa.gov.il/MFA/Terrorism-

+ Obstacle+to + Peace/Palestinian+terror+since $+2000 /$ Victims + of + Palestinian+Violence+and + Terrorism + sinc.ht m? DisplayMode=print. The number of Palestinian victims of direct Palestinian-Israel violence includes the period from 2000-2008. See also Palestine Red Crescent Society: "Total numbers of deaths \& injuries - West
} 


\section{Post-Oslo Initiatives - Institutionalizing and Re-articulating the Discourse}

In this section, I demonstrate that all of the post-Oslo "peace" initiatives were produced in accordance with, reproduced, performed and institutionalized the analytics and practices of the discourse of Palestinian-Israeli relations. Most importantly, I also show that the efforts of the Obama administration to realize a Palestinian-Israeli reconciliation have similarly performed and been performances of the discourse. The post-Oslo "peace" initiatives produced direct Palestinian-Israeli violence culminating in Israel's massacre of Gazans in 2009 and subjected Palestinians to heretofore unrealized levels of structural violence, most glaringly in the form of the medieval siege of Gaza. ${ }^{81}$ As products and reproducers of the discourse, the efforts of the Obama administration, too, can reasonably be expected to renew direct Palestinian-Israeli violence and exacerbate the structural violence to which Palestinians are subject.

\section{1 "Gaza-Bethlehem First" Initiative - 2002}

Israel used the start of the second intifada as a pretext to directly re-conquer all of the West Bank and portions of the Gaza Strip from which it had redeployed during the Oslo Process. The Israeli army directly occupied every Palestinian city and surrounded every Palestinian town in the West Bank. Furthermore, it imposed what Israel calls "internal closure" 82 on the West Bank. This means that Palestinians are not permitted freedom of movement between locations. Israel did not physically re-occupy the Gaza Strip; the Gaza Strip as well as movement between the Strip and Israel has been heavily regulated since the space was literally fenced in by Prime Minister Peres in 1996.

In early August 2002 Israel proffered an initiative ostensibly intended to ease the (re)occupation. Israel proffered a "Gaza-Bethlehem First" initiative. Like the DSOPOISGA and Gaza and Jericho First Agreement (the Cairo Agreement) before it, this 2002 initiative planned Israeli redeployments from Palestinian population centers. Taking an even longer duree perspective, in accordance with the Allon Plan this initiative perpetuated Israeli sovereignty over the Jordan Valley and southern West Bank while relinquishing authority over isolated pockets of Palestinians. Like the Begin Plan's part in the DOPOISGA and Cairo Agreements, this initiative did not involve any military withdrawal, merely redeployment. This is evident from Prime Minister Sharon's statement to reporters defending the initiative: "All in all, a few jeeps and armoured personnel carriers changed their positions in the Bethlehem area and there has been no change in the deployment of the forces in Gaza." 83 Israel continued to retain sovereignty over the land on which the Palestinian population lived.

Bank and Gaza", Palestine Red Crescent Society, at

http://www.palestinercs.org/humanitarian_Arch.aspx?cat_id=20.

${ }^{81}$ Finkelstein contends that the paradigm of war should not be used to describe Israel's attack on the Gaza Strip in late 2008 and early 2009. Finkelstein characterizes it as a "massacre" because the violence was committed by an army against an unarmed civilian, imprisoned population. Ali, Naji: "It's Not About Rockets: Israel's EndGame in Gaza," Crossing the Line: Life in Occupied Palestine, 20 February 2009, at http://ctl.libsyn.com.

${ }^{82}$ The Declaration of Human Rights defines this practice as collective punishment.

${ }^{83}$ Benn, Aluf and Verter, Yossi: "Sharon Downplays Gaza-First program," Ha'aretz, 22 ${ }^{\text {nd }}$ of August of 2002, at http:/www.haaretzdaily.com/hasen/pages/ShArt.jhtml?itemNo=200152\&contrassID=2\&subContrassID=1\&sbS ubContrassID $=0$. 
An extension of "Gaza-Bethlehem First" was discussed in the fall of 2002. This would have involved IDF redeployment from Hebron. ${ }^{84}$ Again, this was a revisiting of the Hebron Protocol which itself was a revisiting of the Allon Plan. Responsibility for the administration of another Palestinian population was to be transferred while Israel was to retain sovereignty over the land.

\subsection{The Roadmap - 2003}

The Quartet's "Performance-Based Roadmap to a Permanent Two-State Solution to the Israeli-Palestinian Conflict" - the Roadmap, was issued in 2003. It, too, institutionalized and re-articulated the discourse of Palestinian-Israeli relations. The opening paragraph of the document referenced President Bush's 24 June 2002 speech in which he imperiously called for a new Palestinian leadership so it is not surprising that the Roadmap demanded reform of the P.N.A. The demands included electoral and legal reform and this reform was institutionalized in the International Task Force on Palestinian Reform. ${ }^{85}$ This was the Quartet, with considerable Israeli input throughout the entirety of the drafting process, determining that the P.N.A. had to be overhauled if it was to serve as an "acceptable" interlocutor for Israel. This was the perpetuation and institutionalization of the second persistent practice.

The Roadmap was also produced in accordance with, and institutionalized, the second and third rules of formation. In the case of the second rule of formation, the document psychologized the Palestinian-Israeli relationship instructing Israel to take no actions that undermined trust between the parties and calling for the resumption of the type of security cooperation associated with the confidence-building measures of the Oslo Process, specifically the Gaza-Jericho Committee. In the case of the third rule of formation, the Roadmap instructed the "reformed" Palestinian leadership to issue an "unequivocal statement reiterating Israel's right to exist in peace and security and calling for an immediate and unconditional ceasefire to end armed activity and all acts of violence against Israelis everywhere." ${ }^{86}$ Israel was instructed to issue an "unequivocal statement affirming its commitment to the two-state vision of an independent, viable, sovereign Palestinian state living in peace and security alongside Israel." ${ }^{87}$ As the third analytic dictates, provided Palestinians realized certain occurrences Israel was willing to permit the establishment of a Palestinian "state" (with provisional borders and ersatz sovereignty).

\subsection{The Geneva Accord - 2003}

The Geneva Accord was “a private Israeli-Palestinian 'civil society' peace initiative",88 announced in October 2003. It was drafted by, among others, Yasir 'Abid Rabbuh

\footnotetext{
${ }^{84}$ Harel, Amos: "Ben-Eliezer to discuss with IDF a possible pullout from Hebron," Ha'aretz, $18^{\text {th }}$ of October of 2002 ,

http://www.haaretzdaily.com/hasen/pages/ShArt.jhtml?itemNo=220519\&contrassID=2\&subContrassID=1\&sbS ubContrassID=0\&listSrc $=Y$; Harel, Amos and Regular, Arnon: "IDF to reduce its presence in Palestinian sections of Hebron," Ha'aretz, $18^{\text {th }}$ of October of 2002, at http://www.haaretzdaily.com/hasen/pages/ShArt.jhtml?itemNo=221209\&contrassID=1\&subContrassID=5\&sbS ubContrassID $=0$ \&listSrc $=$ Y.

${ }^{85}$ U.S. Department of State: "A Performance-Based Roadmap to a Permanent Two-State Solution to the IsraeliPalestinian Conflict" U.S. Department of State, 30 of April of 2003, at http://www.state.gov/r/pa/prs/ps/2003/20062.htm.

${ }^{86}$ Ibid.

${ }^{87}$ Ibid.

88 “The Geneva Accord", op. cit., p. 81.
} 
(Palestinian cabinet minister), Yossi Beilin (former Deputy Foreign Minister), Amram Mitzna (the Labor leader who lost the 2003 election to Sharon), and David Kimche (chief proponent of the "order theory"). The agreement had no official standing, being that it was drafted by Palestinian and Israeli political figures operating in their private capacities, and while it was endorsed by Presidents Carter, Chirac, Clinton, Gorbachev and Mandela and Prime Minister Blair it was rejected, absolutely, by then Israeli Prime Minister Sharon. ${ }^{89}$

The Geneva Accord, too, was produced in accordance with, and perpetuated the persistent analytics and practices of the discourse of Palestinian-Israeli relations. The most notable of the Geneva Accord's seventeen articles involved the defensive characteristics of the Palestinian state, early warning stations and refugees. The agreement stated that "Palestine shall be a nonmilitarized state, with a strong police force" $" 90$ and that "Israel may maintain two EWS [early warning stations] in the northern, and central West Bank." 91 No limitations were imposed on Israeli military forces and that there were no Palestinian early warning stations in Israel. These were restatements of the Clinton Parameters of 2000 - Clinton proposed three Israeli EWS in the West Bank as well as the idea of nonmilitarized Palestine.

These statements abided by, and reproduced, the first, second and third rules of formation as well as the second discursive silence. Arabs/Palestinians were represented as inveterate rejectionists who have victimized Israel. As a result, Israel requires EWS and a nonmilitarized Palestine lest its security be further imperiled through withdrawal from parts of the West Bank and Gaza Strip. An ostensibly sovereign Palestinian state could be established in mandate Palestine provided it met several conditions, most importantly those dealing with security arrangements. And, nothing is said of the fact that Israel's insecurity, which must be assuaged by Palestinian actions and guarantees, is the result of its wars of choice. The Geneva Accord was mute on the manner in which Zionism's drive to maximize territory has afflicted Israel with the insatiable insecurity of the usurper.

Notable as regards refugees, the Geneva Accord stated that: "[t]he parties recognize that, in the context of two independent states, Palestine and Israel, living side by side in peace, an agreed resolution of the refugee problem is necessary for achieving a just, comprehensive and lasting peace between them;" Resolution 242, and the Arab Peace Initiative (Article 2.ii.) concerning the rights of the Palestinian refugees represent the basis for resolving the refugee issue, and agree that these rights are fulfilled according to Article 7 of this agreement." 93 The first statement was discursively standard in that the refugees are represented as a problem, for which responsibility is disclaimed, in need of solution rather than an intended consequence of Jewish Agency, and later Israeli, policy.

The second statement (re-)produced a discursive silence and perpetuated a persistent Jewish Agency/Israeli practice. Despite its broaching of the topic of Palestinian refugees, the Geneva Accord would have permitted only a small number of refugees a return to what is now Israel, and not at their discretion but at Israel's. The options for what the Geneva Accord called the refugee's "Permanent Place of Residence" were Palestine, areas transferred to Palestine by Israel in a land swap, third countries, Israel or present host countries. ${ }^{94}$ According

\footnotetext{
${ }^{89}$ Ibid.

${ }^{90}$ Ibid., p. 85.

${ }^{91}$ Ibid., p. 88.

92 Ibid., p. 95.

${ }^{93}$ Ibid., p. 96.

${ }^{94}$ Ibid.
} 
to the agreement, the number of refugees Israel would "accept" was at its "sovereign discretion." 95 This was so significant a modification to the original intent of Resolution 194 as to make the Accord's reference to the resolution purely political and functionally inoperative.

The Geneva Accord perpetuated the Zionist idea and practice of denying Palestinian nationhood and right to national self-determination even while speaking of refugees. According to David Kimche, Israeli drafters refused to include the word "return" in the accord. Said Kimche of the Geneva negotiations:

[t]owards the end of the session [in the morning at the Movenpick hotel], the Palestinians asked to include the word "return" in the subtitle of the article on refugees. We said, "If you include the word return, we are going to pack our bags and go home. We're not going to accept anything that has to do with return." 96

By excluding the term "return" from the Geneva Accord Israeli negotiators silenced the idea that the refugees would be "going back" to Palestine. This exclusion reproduced the Zionist idea/practice of denying Palestinians attachment to the land of Palestine.

Finally, the second statement concerning Palestinian refugees also perpetuated the Zionist practice of only accepting the partition of Palestine if it is attended by transfer of the indigenous population. According to Masalha: for Zionists "partition was unacceptable without transfer." $"$ Flapan was of the same mind: for Ben-Gurion specifically, and Zionists more generally, "peace was a corollary of transfer." the Geneva Accord made this connection. Article seven to which the statement referred is the end of claims clause. It stated: "[t]his agreement provides for the permanent and complete resolution of the Palestinian refugee problem. No claims may be raised except for those related to the implementation of this agreement." 99 The second statement on refugees effectively said that peace would follow as a practical consequence from the Palestinians' acceptance of their transfer. Phrased differently, the final partition of Palestine and the establishment of a Palestinian state will only occur when Palestinians acquiesce to their transfer. Transfer has always been a Zionist precondition for partition and it continued to be in the Geneva Accord.

\subsection{Sharon's Disengagement Plan - 2004}

Sharon's Disengagement Plan was produced in accordance with, and institutionalized, the persistent analytics and practices of the discourse of Palestinian-Israeli relations. The Disengagement Plan had two prongs: 1) Israeli military redeployment to the perimeter of the Gaza Strip, rather than in it, and 2) construction of the "security fence." The first prong also involved the evacuation of Israeli settlements in the Gaza Strip. Together these two actions perpetuated persistent Zionist/Israeli practices, inter alia, transfer and territorial maximization.

\footnotetext{
${ }^{95}$ Ibid.

96 Light, Gilead: "The Lesser Price to Pay: An Interview with an Israeli member of the Geneva initiative delegation", Israel Policy Forum, $4^{\text {th }}$ of December of 2003, at http://www.israelpolicyforum.org/analysis/lesserprice-pay.

${ }_{97}^{97}$ Masalha, op. cit., p. 68.

${ }^{98}$ Flapan, Simha (1987): The Birth of Israel: Myths and Realities, 1st ed. New York, Pantheon Books, p. 104.

99 "The Geneva Accord," op. cit., p. 97.
} 
Sharon's much heralded unilateral disengagement from Gaza did not represent a policy departure for the state of Israel. Israel wanted to get out of Gaza since it occupied the strip. Israel offered the Gaza Strip to Egypt in 1967 at the conclusion of the war as part of an armistice, seeing in the territory no religious or strategic significance and an obvious demographic liability. Israel's abhorrence and fear of the Gaza Strip, particularly after the start of the first intifada, was stated quite clearly in 1992 by then Prime Minister Rabin when he expressed the wish that the Gaza Strip "would fall into the sea." ${ }^{100}$ Rabin quickly added "that since that won't happen, a solution must be found for the problem." ${ }^{\text {"101 }}$ In 1994, Israel built a 64-kilometer encirclement fence around the Gaza Strip. In 1995, the solution to the Israeli problem with the Gaza Strip was crafted in the form of the Oslo II Agreement. The Oslo II Agreement transferred responsibility for Gaza, except for the settlements and bypass roads in the territory, to the Palestinian Authority. It appeared that Israel was finally rid of the Gaza Strip, until the start of the Al-Aqsa intifada and the Israeli military incursions into the strip. As a result of these actions, Israel again tried to divest itself of the Gaza Strip in 2002 by proffering the "Gaza-Bethlehem First" initiative. The Gaza Strip dimension of Sharon's Disengagement Plan was the solution to Israel's problem with Gaza's demographics.

The Gaza Strip dimension of the Disengagement Plan perpetuated three persistent Israeli practices: 1) render Palestinians irrelevant to the final dispensation of mandate Palestine; 2) transfer; and 3) maximize territory. Perpetuation of the first practice was evident in the fact that the plan was a unilateral action. Palestinians were excluded from the political machinations surrounding Israel's redeployment. Sharon acknowledged as much in his speech announcing the plan saying that " $[\mathrm{t}]$ he unilateral steps which Israel will take in the framework of the 'Disengagement Plan' will be fully coordinated with the United States." 102 Later Sharon also tellingly said that " [t] he 'Disengagement Plan' will include the redeployment of IDF forces along new security lines and a change in the deployment of settlements, which will reduce as much as possible the number of Israelis located in the heart of the Palestinian population. We will draw provisional security lines and the IDF will be deployed along them." $" 103$ Conspicuous by its absence from both statements is any mention of the Palestinian Authority. The redeployment was not coordinated with the Palestinian Authority, but with the U.S. The lines of the redeployment were not drawn in consultation with the Palestinian National Authority. Redeployment was an exclusively Israeli action, the consequences of which were imposed on Palestinians.

Second, Israel's redeployment around the Gaza Strip transferred responsibility for the Palestinian population of the territory to the P.N.A. According to the "Report of the Special Rapporteur of the Commission on Human Rights":

Israel has announced that it will withdraw unilaterally from Gaza. Israel intends to portray this as the end of the military occupation of Gaza, with the result that it will no longer be subject to the Fourth Geneva Convention in respect to Gaza. In reality, however, Israel does not plan to relinquish its grasp on the Gaza Strip. It plans to retain ultimate control over Gaza by controlling its borders, territorial sea

\footnotetext{
${ }^{100}$ Resolution United Nations General Assembly 194 (III) (1948): Palestine - Progress Report on the United Nations Mediator, at http://domino.un.org/UNISPAL.NSF/0/c758572b78d1cd0085256bcf0077e51a?OpenDocument. ${ }^{101}$ Ibid.

102 "Doc. C1. Prime Minister Ariel Sharon, Speech Outlining a Unilateral 'Disengagement Plan'," Journal of Palestine Studies, Vol. 33, No. 3 (2004), pp.165-166.

103 "Doc. C1...., op. cit., p. 166.
} 
and airspace. Consequently, it will in law remain an Occupying Power still subject to obligations under the Fourth Geneva Convention. ${ }^{104}$

By evacuating the Gaza Strip, and claiming to end its occupation of the territory, Israel tried to divest itself of responsibility for Gazan Palestinians and impose this responsibility, unilaterally, on the remnants of the P.N.A.

In the Gaza Strip dimension of the Disengagement Plan we see the transfer of responsibility for Palestinians from Israel to another party. Where historically Zionism had hoped that this party would be Jordan in accordance with the "Jordanian option," through disengagement it became what little remained of the P.N.A. in the Gaza Strip. The practice of transfer was the same - Israel divested itself of a non-Jewish population while controlling the territory of this population; the recipient responsible for the transferred population was changed.

Finally, Israel's redeployment around the Gaza Strip perpetuated the practice of territorial maximization. Now, how did a military redeployment to the perimeter of the Gaza Strip maximize Israeli territory? First, as the UN Special Rapporteur of the Commission on Human Rights noted, redeployment did not mean that Israel was relinquishing control of the Gaza Strip. Second, and more importantly, redeployment from the morass that is the Gaza Strip paid territorial dividends for Israel in the West Bank. Sharon redeployed from the Gaza Strip to remain in the West Bank.

According to the Foundation for Middle East Peace:

$[\mathrm{m}]$ ost of the plans for separation or unilateral withdrawal now under discussion, including the one supported by the Sharon government, are first and foremost the product of an Israeli desire not to separate - to remain in the territories in both the security and settlement dimensions - from the West Bank and Gaza Strip. ${ }^{105}$

This assertion, and the persistence of the Israeli practice of territorial maximization, was borne out by Sharon's own comments on the Disengagement Plan and Bush's guarantees to Sharon in April 2004. In the same speech in which he outlined Israel's disengagement from the Gaza Strip Sharon also stated that: "[a]t the same time [as redeployment around the Gaza Strip and relocation of Israeli settlements], in the framework of the 'Disengagement Plan,' Israel will strengthen its control over those same areas in the Land of Israel which will constitute an inseparable part of the State of Israel in any future agreement."106 "Those same areas in the Land of Israel" are located in the West Bank. The envisioned territorial dividends were realized by Sharon in April 2004 when correspondence from Bush to Sharon assured

\footnotetext{
${ }^{104}$ John Dugard, Special Rapporteur of the Commission on Human Rights, "E/CN.4/2005/29 Question of the Violation of Human Rights in the Occupied Arab Territories, including Palestine: Report of the Special Rapporteur of the Commission on Human Rights, John Dugard, on the situation of human rights in the Palestinian territories occupied by Israel since 1967", United Nations, $7^{\text {th }}$ of December of 2004, at http://domino.un.org/UNISPAL.NSF/0/9c172354fe3c565785256f8e006f3988? OpenDocument.

${ }^{105}$ Foundation for Middle East Peace: Report on Israeli Settlement Activity in the Occupied Territories, Vol. 12 , No. 3 (2002), p. 4.

106 "Doc. C1....", op. cit., p. 166.
} 
Israel that it would retain its large settlements in the West Bank in any final status agreement. Said Bush:

As part of a final peace settlement, Israel must have secure and recognized borders, which should emerge from negotiations between the parties in accordance with UNSC Resolutions 242 and 338. In light of new realities on the ground, including already existing major Israeli populations [sic] centers, it is unrealistic to expect that the outcome of final status negotiations will be a full and complete return to the armistice lines of 1949, and all previous efforts to negotiate a two-state solution have reached the same conclusion. It is realistic to expect that any final status agreement will only be achieved on the basis of mutually agreed changes that reflect these realities. ${ }^{107}$

"Already existing major Israeli population centers" are settlements in the West Bank such as Ariel and Ma'ale Adumim, and according to Bush they would not have to be surrendered by Israel in any final status negotiations with the Palestinians. Redeployment around the Gaza Strip further consolidated Israeli control over the West Bank and this, of course, was the perpetuation of the Israeli practice of territorial maximization.

The second prong of the Disengagement Plan was construction of Israel's "security fence." "108 Like the Gaza Strip dimension of the plan, this "fence" was neither an ideational or policy departure for Zionism and Israel. In the early $20^{\text {th }}$ century the Revisionist Zionist Jabotinsky argued in favor of an "Iron Wall:" "[w]e must either suspend out settlement efforts or continue them without paying attention to the mood of the natives. Settlement can thus develop under the protection of a force that is not dependent on the local population, behind an iron wall which they will be powerless to break down." 109 According to Shlaim, "Ze'ev Jabotinsky's strategy of the iron wall was designed to force the Palestinians to despair of the prospect of driving the Jews out of Palestine and to compel them to negotiate with the Jewish state from a position of weakness." 110 It would be a mistake, however, to understand the idea of an "Iron Wall" or "security fence" as an exclusively Revisionist Zionist or Likud one. In this sense, Makovsky is right in identifying Rabin as the intellectual father of the "fence." In 1994 Rabin started building the already mentioned Gaza encirclement fence; in 1995 Rabin

107 “Doc. B. U.S. President George W. Bush, Letter to Israeli Prime Minister Ariel Sharon on the Disengagement Plan," Journal of Palestine Studies, Vol. 33, No. 4 (2004), pp. 89-90.

${ }^{108}$ B"'Tselem describes the "security fence" as follows: "The main component of the barrier is an electronic fence that will give warning of every attempt to cross it. Along the east side of the fence is a 'service road' bordered by a barbed-wire fence. East of the service road is a 'trench or other means intended to prevent motor vehicles from crashing into and through the fence.' The plan calls for three paths to the west of the fence: 'a trace road, intended to reveal the footprints of a person who crossed the fence, a patrol road, and an armored vehicles road.' Another barbed-wire fence will be constructed along this path. The average width of the barrier complex is sixty meters. Due to topographic constraints, a narrower barrier will be erected in some areas and will not include all of the elements that support the electronic fence. However, as the state indicated to the High Court of Justice, 'in certain cases, the barrier will reach a width of one hundred meters due to the topographic conditions'." Lein, Yehezkel (2003): Behind the Barrier: Human Rights Violations As a Result of Israel's Separation Barrier. Jerusalem, B'Tselem - The Israeli Information Center for Human Rights in the Occupied Territories, p. 8.

${ }^{109}$ Shlaim, op. cit., p. 13.

${ }^{110}$ Ibid., p. 606.

${ }^{111}$ Makovsky, David: “A Defensible Fence: How to build a West Bank barrier that encourages peace”, Australia/Israel \& Jewish Affirs Council, August of 2004, at http://www.aijac.org.au/review/2004/298/essay298.htm. For similar ideas see also: Makovsky, David: "The Right Fence for Israel," Foreign Affairs, Vol. 83, No. 2 (2004), pp. 50-64. 
established the Shahal Commission (after inter-ministerial committee headed by Moshe Shahal, his police commissioner) to determine the optimal means of building a security barrier in the West Bank;" "112 in 1996 "Peres approved the construction of a two-kilometrewide 'buffer zone' to run along the 350-kilometre West Bank-Israel Green Line;" 113 and in 2000 Barak "ordered Deputy Defence Minister Ephraim Sneh to prepare a team to draw a partition line between Israel and the West Bank, paralleling Rabin's Shahal Commission."114 Like the idea and practice of transfer and the practice of settlement, the "security fence" is a longstanding Zionist idea shared by Israel's mainstream political parties. Sharon co-opted "a popular idea reared by the Israeli Center-Left" ${ }^{, 15}$ and broadened its appeal to the Israeli public by moving it eastward, ${ }^{116}$ absorbing more West Bank territory (including Israeli settlers and settlements and Palestinian villages and land) into Israel.

A number of analytics and practices came into play in the construction of the "security fence." First, the idea/practice of territorial maximization and persistence of the Israeli practice of settlement were readily apparent. The "fence" is largely built in the West Bank, on land expropriated from Palestinians. According to the UN's Special Rapporteur of the Commission on Human Rights:

[a] further purpose of the Wall is to expand Israel's territory. Rich agricultural land and water resources along the Green Line have been incorporated into Israel. In recent months, Israel has manifested its territorial ambitions in the Jerusalem area. The Wall is currently being built around an expanded East Jerusalem to incorporate some 247,000 settlers in 12 settlements and some 249,000 Palestinians within the boundaries of the Wall. $^{117}$

Regarding the persistent practice of settlement, Lagerquist states that: "[i]f most parties along Israel's political spectrum can identify with the map now drawn by the fence it is because it closely follows one that for over thirty years has served as a referent for Israeli debates about the West Bank - that of the Allon Plan."118

Second, the idea/practice of transfer informed, and was institutionalized in, the "fence." Lagerquist asserts that transfer looms at the conclusion of the "fence." to him, Palestinians have good reason to fear that the "fence" will realize "a demographic housecleaning in the West Bank." 120 The UN's Special Rapporteur of the Commission on Human Rights came to the same, if more geographically restricted, conclusion:

[Another] purpose of the Wall is to compel Palestinian residents living between the Wall and the Green Line and adjacent to the Wall, but separated from their land by

\footnotetext{
112 Makovsky, "A Defensible Fence...", op. cit.

${ }^{113}$ Usher, Graham (1999): Dispatches From Palestine: The Rise and Fall of the Oslo Process. London, Pluto Press, p. 99.

${ }^{114}$ Makovsky, “A Defensible Fence...”, op. cit.

${ }^{115}$ Lagerquist, Peter: "Fencing the Last Sky: Excavating Palestine After Israel's 'Separation Wall'," Journal of Palestine Studies, Vol. 33, No. 2 (2004), p. 6.

${ }^{116}$ Ibid., p. 7.

${ }^{117}$ Dugard, op. cit.

${ }^{118}$ Lagerquist, op. cit., p. 10.

119 Ibid., p. 5.

${ }^{120}$ Ibid., p. 21.
} 
the Wall, to leave their homes and start a new life elsewhere in the West Bank, by making life intolerable for them. Restrictions on freedom of movement in the "Closed Zone" between the Wall and the Green Line and the separation of farmers from their land will be principally responsible for forcing Palestinians to move. ${ }^{121}$

Whether Palestinians are forced from land adjacent to the "fence" or forced from the West Bank entirely, through construction of the "security fence" Israel is forcibly removing Palestinians from territory it covets. The "fence" is yet another instance of Israel attempting to reconcile its territorial ambitions with demographic concerns.

Third, the idea/practice of deeming Palestinians irrelevant to the final dispensation of mandate Palestine was present in the construction of the "fence." This is most obvious in the fact that the route of the "fence" was determined by the Israeli Ministry of Defence. Admittedly, there was discussion between Israel and the U.S. as to the exact location and route of the "fence." This is hardly surprising; recall that in announcing the Disengagement Plan Sharon explained that Israel's unilateral steps would be coordinated with the U.S. ${ }^{122}$ This Israeli-American coordination was acknowledged by Ross:

\begin{abstract}
With the Israelis, the United States would coordinate on the route of the security barrier to ensure that it makes infiltration into Israel difficult, minimizes the numbers of Palestinians Israel would absorb, imposes the fewest possible hardships on Palestinian villages affected by the barrier, and preserves the possibility of an eventual two-state solution in time. ${ }^{123}$
\end{abstract}

Ross' empty concern for the hardships of Palestinians aside, his statement clearly indicates that Palestinians were excluded from discussions involving the "fence." The "security fence" is "the most far-reaching reordering of the Palestinian landscape undertaken since 1967" 124 and Palestinians are irrelevant to this reordering; Israeli policy exclusively dictates it.

In 2003, the Foundation for Middle East Peace explained that "Israel is refining its ideas with the United States rather negotiating with the Palestinian Authority, which the two parties have turned into a moribund shadow of its former self." 125 This, of course, was in keeping with established idea and practice. As was the case in the procurement of the Balfour Declaration and negotiations surrounding the 1947 Partition Resolution, Israel was coordinating the dispensation of Palestine with the hegemon of the day and ignoring the natives in situ.

\title{
4.5 The Annapolis Conference and Olmert's Proposal - 2007-2008
}

The texts of and following from the Annapolis Conference of 2007 were also produced by, and reproduced, the discourse of Palestinian-Israeli relations. More specifically, the first and second silences, all the rules of formation and the third persistent practice governed and/or

\footnotetext{
${ }^{121}$ Dugard, op. cit.

122 "Doc. C1. Prime Minister Ariel Sharon, Speech Outlining a Unilateral 'Disengagement Plan', Journal of Palestine Studies, Vol. 33, No. 3 (2004), pp. 166-167.

${ }^{123}$ Ross, op. cit., p. 778.

${ }^{124}$ Lagerquist, op. cit., p. 5.

${ }^{125}$ Foundation for Middle East Peace, Report on Israeli Settlement Activity in the Occupied Territories, Vol. 13, No. 4 (2003), p. 4.
} 
were performed in the statements by Bush, Abbas and Olmert as well as Olmert's proposal the following year.

Bush, Abbas and Olmert were all silent regarding the Zionist idea and practice of transfer. Instead of citing the historic and ongoing ethnic cleansing of Palestine, Bush said "violence... has been the true enemy of the aspirations of both the Israelis and Palestinians." He also twice recognized Israel as a Jewish state and homeland for the Jewish people. ${ }^{126}$ This was tacit acknowledgment that he would not work towards the repatriation of Palestinian refugees to their homes and property in what is now Israel. Unforgivably, Abbas, too, was silent regarding transfer. In speaking about the rights belonging to Palestinians that would make them equal to people around the world he referenced only "the right to independence and self-determination." 127 He said nothing about the refugees' internationally recognized right to return to their property in Israel. Predictably, Olmert said nothing about Israel's ethnic cleansing of Palestine. His contribution on this point was to reaffirm previous agreements, including Bush's 14 April 2004 letter to Sharon which abrogated the right of return by declaring "that the solution to the Palestinian refugee issue must be found 'through the establishment of a Palestinian state, and the settling of Palestinian refugees there, rather than in Israel'.,"128

Bush, Abbas and Olmert were similarly silent regarding the fact that Zionism is a conquest movement. Bush and Abbas talked about the occupation, but did not historicize it. There was no acknowledgment by either that Israel occupies Palestinians in the West Bank and Gaza Strip as a result of an aggressive war of its choosing. Olmert was categorical in his silencing of the history of Zionism's/Israel's subjugation of Palestinians and expropriation of their resources by force of arms: "I came here today not in order to settle historical accounts between us and you about what caused the confrontations and the hatred, and what for many years has prevented a compromise, a settlement of peace."129

Furthermore, the Bush, Abbas and Olmert statements were all produced in accordance with the three rules of formation governing the discourse of Palestinian-Israeli relations. Both Bush and Olmert represented Israel as peace-seeking. Said Bush: "[s]uch a [Palestinian] state will help provide the Israelis with something they have been seeking for generations: to live in peace with their neighbors." 130 Said Olmert: "I came here today...to extend a hand in peace, a hand which marks the beginning of historic reconciliation between us and you, the Palestinians, and all Arab nations." ${ }^{131}$ Abbas offered no contradictory narrative, either of Arabs/Palestinians as compromising or of Zionism/Israel as conqueror. The Bush and Olmert statements also conformed to the second rule. Bush dehistoricized and psychologized the Palestinian-Israeli relationship, talking about "hopelessness and despair" rather than about the material deprivation and direct and structural violence of the occupation. He also used the partnership language and referenced the confidence-building mechanisms of the second rule: " $[t]$ he emergence of responsible Palestinian leaders has given Israeli leaders the confidence

\footnotetext{
126 "Special Document File The Annapolis Conference: B. U.S. Pres. George W. Bush, Opening Statement to the Annapolis Conference, 27 November 2007 (excerpts)," Journal of Palestine Studies, Vol. 37, No. 3 (Spring 2008), pp. 77-80.

127 "Special Document File The Annapolis Conference: Palestinian Pres. Mahmud Abbas, Statement to the Annapolis Conference, 27 November 2007 (excerpts)," Journal of Palestine Studies, Vol. 37, No. 3 (Spring 2008), p. 82.

128 "Special Document File The Annapolis Conference: Israeli PM Ehud Olmert, Statement to the Annapolis Conference, 27 November 2007 (excerpts)," Journal of Palestine Studies, Vol. 37, No. 3 (Spring 2008), p. 83.

${ }^{129}$ Ibid., p. 84.

130 “Special Document File The Annapolis Conference: B. U.S. Pres. George W. Bush...", op. cit., p. 77.

131 “Special Document File The Annapolis Conference: Israeli PM Ehud Olmert...”, op. cit., p. 83.
} 
they need to reach out to the Palestinians in true partnership."132 Olmert magnanimously posited a symmetry in the Palestinian-Israeli relationship: "I acknowledge the fact that alongside the constant suffering that many in Israel have experienced...your people, too, have suffered for many years, and there are some who still suffer." 133 Then, like Bush, Olmert psychologized the relationship speaking only to the "pain and this humiliation [which] are the deepest foundations which fomented the ethos of hatred toward us."134 Again, Abbas offered no countervailing representations. Finally, in suggesting Palestinians would be granted a "state," provided they met certain conditions, Bush's statement was in keeping with the third rule of formation:

[f]or these negotiations to succeed [and realize the goal of two states as expressed
by the Israel-P.L.O. "Joint Understanding"], the Palestinians must do their part.
They must show the world they understand that while the borders of a Palestinian
state are important, the nature of a Palestinian state is just as important. They must
demonstrate that a Palestinian state will create opportunity for all its citizens, and
govern justly, and dismantle the infrastructure of terror. They must show that a
Palestinian state will accept its responsibility, and have the capability to be a source
of stability and peace - for its own citizens, for the people of Israel, and for the
whole region.

The Palestinians receive a ersatz sovereign state provided they meet provisions established by Israel. The statements of the Annapolis Conference were articulated in accordance with the analytics, the silences and the rules of formation, of the discourse of Palestinian-Israeli relations.

Following on from the Annapolis Conference, in September 2008 Olmert "proposed giving the Palestinians land from communities bordering the Gaza Strip and the Judean Desert nature reserve in exchange for settlement blocs in the West Bank." 136 More specifically, Olmert wanted to annex to Israel 6.3 percent of the West Bank, including settlements containing 75 percent of the Jewish settler population. In exchange "Olmert proposed the transfer of territory to the Palestinians equivalent to 5.8 percent of the area of the West Bank as well as a safe-passage route from Hebron to the Gaza Strip via a highway that would remain part of the sovereign territory of Israel but where there would be no Israeli presence." 137 The proposal involved Israel evacuating, inter alia, settlements in the Jordan Valley and places in and around Hebron. Olmert's proposal embodied the four elements common to all of Israel's pre-Oslo "peace" initiatives, namely the Allon, Begin and Shamir Plans: it would have denied Palestinians their right to national self-determination - no state composed of noncontiguous territories cleaved by another sovereign entity is sovereign, annexed large tracts of land to Israel, transferred responsibility for the Palestinians of the West Bank to a Palestinian administration and continued Israeli sovereignty over a large chunk, the settlement blocs, of the West Bank. Olmert's 2008 proposal amounted to yet

\footnotetext{
132 “Special Document File The Annapolis Conference: B. U.S. Pres. George W. Bush...”, op. cit., p. 78.

133 "Special Document File The Annapolis Conference: Israeli PM Ehud Olmert...", op. cit., p. 84.

134 Ibid.

135 “Special Document File The Annapolis Conference: B. U.S. Pres. George W. Bush...”, op. cit., p. 79. My emphasis added.

136 "Document C2. Aluf Benn, Ehud Olmert's Plan for Peace with the Palestinians, Ha'aretz, 17 December 2009

(Excerpts)," Journal of Palestine Studies 39, no. 3 (Spring 2010), 206.

137 Ibid.
} 
another performance of the persistent Israeli practice of proffering initiatives ostensibly aimed at ending Israel's occupation of the West Bank and Gaza Strip.

\subsection{Obama's Efforts - 2009-2010}

Obama's recent efforts at Palestinian-Israeli reconciliation, most specifically his push for direct talks between the parties at the end of 2010, are clearly products of, and reproduce, the discourse of Palestinian-Israeli relations. All the discourse's silences, rules of formation and persistent practices are evident in the initiatives of the Obama administration.

Not only has the Obama administration said absolutely nothing about the ethnic cleansing of Palestine, it has actually encouraged Palestinians to accept their transfer. In October, Netanyahu "offered a 'limited' extension of the partial settlement freeze if the Palestinians recognized Israel as the nation-state of the Jewish people." When Abbas rejected the proposal, the U.S. State Department "suggested...that Abbas make a counteroffer to keep the process going." 138 The U.S. encouraged the Palestinians to negotiate away their inalienable right of return. The following month, a joint press statement issued after a Clinton and Netanyahu meeting in New York "called for an agreement that 'reconciles the Palestinian goal of an independent and viable state based on the 1967 lines, with agreed swaps, and the Israeli goal of a Jewish state with secure and recognized borders." 139 Israel can only be realized as a Jewish state through negation of the Palestinians' right of return "since if their right is recognized, there will be no part of Palestine that could be guaranteed in law and in practice to remain demographically exclusively 'Jewish', not even the greater Metropolitan area of Tel Aviv." 140 Clinton's statement pledges the U.S. to the indefinite transfer of Palestinians and perpetuates the practice of making a Palestinian state and peace a corollary of transfer.

The Obama administration has been similarly silent regarding the fact that Zionism, institutionalized in the state of Israel, is a conquest movement. The Obama administration has said nothing about Israel's aggressive wars of choice, and it certainly could have, given that it was coming into office as Israel massacred Gazans with "Operation Cast Lead." In fact, the administration has sought to reward Israel for its expropriation and exploitation of Palestinian land and resources. In September, Ehud Barak, Israel's Defense Minister, was negotiating a "lucrative 'incentives package' from the U.S." in exchange for an extension of the settlement "freeze" then in effect. ${ }^{141}$ According to reports, the U.S. offered to reward Israel for its conquest of the West Bank with the following pledges:

(1) to support a long-term Israeli presence along the eastern border of a future Palestinian state as part of a final status agreement, (2) to veto any UN Security Council (UNSC) resolutions relating to Arab-Israeli peace for 1 year, (3) to provide the IDF [Israeli Defense Forces] advanced military hardware (missile systems, aircraft, satellites), (4) to work for a regional security agreement that would defend Israel against threats from Iran, (5) to help enforce the ban on weapons smuggling into a Palestinian state (i.e., endorsing Israel's final status

\footnotetext{
${ }^{138}$ Esposito, op. cit., p. 128.

139 Ibid., p. 131.

${ }^{140}$ Davis, Uri (2003): Apartheid Israel: Possibilities for the Struggle Within. New York, London, p. 62.

${ }^{141}$ Esposito, op. cit., p. 125. The "freeze" was only ever partial. It "did not include East Jerusalem, infrastructure or public-use construction (e.g. schools, synagogues) in West Bank settlements, or West Bank settlement housing units already under construction”. See Esposito, op. cit., p. 105.
} 
demand for a demilitarized Palestinian state); and (6) not to ask for any further extensions of the settlement freeze. ${ }^{142}$

The incentives were so far-reaching, and the exercise of two parties negotiating over the property of a third so blatant, that the White House offer was dubbed, not inaccurately, "Obama's Balfour Declaration."143 Not only has the Obama administration been silent regarding Israel's territorial desideratum, Israel's relentless usurpation has induced the U.S. to offer Israel unprecedented rewards if partial settlement will only stop momentarily.

The Obama administration recently articulated a statement that bears on the third silence, but not in a manner that violates the silence. As a result of the Clinton-Netanyahu meeting in November, the "U.S. pledge[d] to block any UNSC measure that "would try to shape a final peace agreement,' especially any resolution seeking international recognition of Palestinian statehood without Israeli agreement." "Th4 The silence of the Obama administration regarding Israel's denial of Palestinian nationhood and national self-determination is understandable given that the U.S. is colluding with Israel in this denial. The Obama administration is silent about Israel's denial of Palestinian nationhood and is, moreover, thwarting the realization of Palestinian national self-determination.

At first blush the Obama administration seems to articulate statements in violation of the first rule of formation. To think that the Obama administration does not represent Israel as peace-seeking, for example, would be to misread its statements however. An instructive episode occurred in November after Israel's Interior Ministry announced 1,300 new Jewish settlements in occupied Jerusalem. Obama "stated that such moves undermined trust and signaled that Israel was not making 'the extra effort' to achieve peace."145 Putting aside Obama's psychologizing of the Palestinian-Israeli relationship for the moment (he could have made the material point that the settlements were built on land expropriated from Palestinians), it must be recognized that this supposed critique of Israel was actually expressed in accordance with the first rule. Obama's statement was informed by the assumption that Israel makes efforts towards peace; it is just not doing anything in excess of its usual efforts.

In addition to Obama's preceding statement about undermining trust between Palestinians and Israel, other recent efforts by the administration have also faithfully subscribed to the second rule of formation. In pushing for the start of direct Palestinian-Israeli talks over the summer of 2010, the Obama administration stopped pressuring Israel and "instead urged the Palestinians to resume direct talks to boost Israel's 'confidence' and 'create a climate' that could lead to breakthroughs." The Obama administration urged Palestinians to reassure victimized Israel and take steps assuaging Israel's incredulity regarding their interests in peace. Later in the summer the U.S. government paid for the Palestinians to run one-minute videos "by half a dozen Palestinian negotiators (including chief negotiator Erakat...) with the message 'I am your partner. Are you mine?' and expressing the serious Palestinian desire for lasting peace on electronic billboards across Israel and on Israeli [w]ebsites online."146 As dictated by the second discursive rule of formation, the Obama administration has made

\footnotetext{
${ }^{142}$ Ibid., pp. 125-126.

143 Ibid., p. 126.

${ }^{144}$ Ibid., pp. 131-132.

${ }^{145}$ Ibid., p. 131.

${ }^{146}$ Ibid., pp. 121-122.
} 
statements psychologizing the Palestinian-Israeli relationship and deploying the language of "partnership" that occults Israel's long history of occupation and expropriation of land and resources in the West Bank and Gaza Strip.

As the texts following the November Clinton-Netanyahu meeting indicate, the Obama administration is talking about "an independent and viable Palestinian state," provided it is an ersatz sovereign state to which Israel agrees. This is clearly in keeping with the third rule of formation. An even more obvious example of the Obama administration performing the discourse in accordance with this rule was Mitchell's attempt to create a "framework agreement" in August. The agreement Mitchell was trying to craft was in keeping with the second rule of formation as it adumbrated "the compromises each side must be ready to make' to achieve peace." It also made clear that it was not the final agreement that was to be completed within a year, but only a prelude to it, in other words, a new interim agreement that would give the sides as many as 10 years to finalize a comprehensive final status treaty." Like the Allon and Begin Plans and DOPOISGA before it, the Obama administration's Mitchell agreement sought to craft an interim agreement through which Israel could dictate the contours and constitution of any Palestinian "state" in mandate Palestine.

Mention of the Allon and Begin Plans raises the issue of the persistent practices constituting the discourse. Regarding settlement, even before the partial settlement "freeze" ended in September settlers seized land and expanded three settlements near Salfit and Bethlehem. Within weeks settlers

had started work on some 600 housing units in at least 36 settlements... Many of the units were going up in areas that under most peace scenarios would become part of a Palestinian state.... With the new housing starts, Israel's total construction for 2010 was expected to reach 3,000 units - equal to the combined housing construction for $2006-8 .{ }^{148}$

Since taking office, not only has the Obama administration allowed Israel's settlement practice to persist, by offering "lucrative incentive packages" and celebrating the settlement "freeze" it has encouraged acceleration of the practice.

The second practice of producing interlocutors "acceptable" to Israel has also persisted. This was most readily evident in Israel's recent settlement "freeze." Abbas' term as P.N.A. president expired in January 2009, was extended on questionable legal grounds, and expired again in January 2010. This, coupled with HAMAS' parliamentary victory in 2006 and subsequent ascendancy in the occupied Gaza Strip, has meant that Abbas faces a serious legitimacy crisis. The U.S. and Israel used the settlement "freeze" as a means of bolstering Abbas' political fortunes and legitimacy. Immediately prior to Netanyahu's announcement of the settlement "freeze" Israel approved the construction of 900 new housing units in the Gilo settlement. The Gilo announcement "was seen by the U.S. as 'one more nail in Abbas' political coffin'." 149 At the same time Israel's security apparatus was "in a state of alarm over [Abbas's] possible departure" after he had announced that he would not seek re-election and might even resign early. ${ }^{150}$ Netanyahu announced the "freeze" at least in part to maintain

\footnotetext{
${ }^{147}$ Ibid., p. 123.

${ }^{148}$ Ibid., p. 130.

149 Ibid., p. 112.

${ }^{150}$ Ibid., p. 111.
} 
Abbas in his position in the Palestinian polity. Bolstering Abbas also explains why the Obama administration welcomed the November "freeze" as "significant" when essentially the same proposal was offered earlier in June and rejected by the U.S. as insufficient. ${ }^{151}$ In the past Israel has employed elections and funding as mechanisms to produce "acceptable" interlocutors, be they West Bank mayors or Islamists, under the Obama administration it has used the settlement "freeze" to relatively empower Abbas and the P.N.A.

Finally, since the Obama administration came to office the U.S. and Israel have both perpetuated the third practice of the discourse. As already mentioned, Mitchell's "framework agreement" amounted to another revisiting of the interim, less than sovereign Palestinian authority envisioned by the Begin Plan, and Obama's Balfour Declaration, in accordance with the Clinton Parameters, pledged the U.S. to realize a "demilitarized Palestinian state." On Israel's part, and again in keeping with the Clinton Parameters, Netanyahu asserted in August that an agreement with the Palestinians must be based on: "(1) sustainable security arrangements; (2) recognition of Israel as 'the national state of the Jewish people,' meaning that any return of Palestinian refugees would be 'realized in the territory of the Palestinian state'; and (3) acceptance that the agreement would mark the end of claims between Israel and 'a demilitarized Palestinian state'."152 In September, he sought "U.S. guarantees that Israel would keep a long-term military presence in the Jordan Valley under final status," "153 even going so far as to reject a U.S. proposal that Israel lease large parts of the Jordan Valley for seven years with the response that "anything less than a 99-year lease is not worth talking about." 154 This emphasis on Israel retaining de facto sovereignty over the Jordan Valley is, of course, in keeping with the Allon Plan. The period of the Obama administration has been characterized by the U.S. and Israel proffering unoriginal initiatives ostensibly aimed at ending Israel's occupation of the West Bank and Gaza Strip which would, in reality, provide Palestinians with something considerably less than a sovereign state.

All of the post-Oslo "peace" initiatives - "Gaza-Bethlehem First", the Roadmap, the Geneva Accord, the Disengagement Plan, the Annapolis Conference - were articulations of the discourse of Palestinian-Israeli relations. They were produced in accordance with, reproduced and institutionalized the analytics and practices of the discourse. Importantly, they also all produced direct Palestinian-Israeli violence and subjected Palestinians to extremely oppressive levels of structural violence. The efforts of the Obama administration to effect a Palestinian-Israeli reconciliation have similarly performed and been performances of the discourse. Obama's efforts cannot reasonably be expected to succeed in producing peace between Palestinians and Israel where similar textual products of the same discourse failed. In fact, precedent indicates that Obama's efforts will result in renewed direct violence between the parties and an exacerbation of the structural violence to which Palestinians are subject.

\section{Conclusion}

Palestinian-Israeli relations, textually and materially, are governed and performed in accordance with a discourse. The discourse is comprised of six analytics and three persistent practices. The three silences exclude discussion of: 1) the Zionist idea and practice of transfer, 2) Zionism's territorial desideratum, and 3) Zionism's denial of Palestinian nationhood and

\footnotetext{
151 Ibid., p. 112.

152 Ibid., p. 121.

${ }^{153}$ Ibid., p. 125.

${ }^{154}$ Ibid., p. 129.
} 
right to national self-determination. The three rules of formation require that: 1) Arabs/Palestinians be represented as rejectionists and Israel be represented as compromising and peace-seeking, 2) Israel be represented as the victim in the Palestinian-Israeli relationship, or that the relationship be represented as symmetrical, and 3) the assumption be made that Zionism/Israel would permit the establishment of a sovereign Palestinian state in mandate Palestine. The three persistent practices involve: 1) Israeli settlement, 2) Israel producing Palestinian interlocutors it finds "acceptable" and 3) Israel proffering initiatives ostensibly aimed at ending the occupation of the West Bank and Gaza Strip.

The 1993 start of the Oslo Process did not mark a discursive breakthrough in Palestinian-Israeli relations. In fact, the Oslo agreements, be it the DOPOISGA or the Protocol on Further Transfer of Powers and Responsibilities for example, were produced in accordance with, reproduced and institutionalized the analytics and practices of the discourse. This articulation of the discourse culminated in the then new violence of the al-Aqsa intifada. Since 2000, the discourse has performed, and been performed in, all manner of "peace" initiatives - both state and civil society sponsored, unilateral, bilateral and multilateral - and each has produced increasing levels of direct and structural violence.

Like all the other post-Oslo initiatives, the efforts of the Obama administration, too, have been products of and reproduced the discourse of Palestinian-Israeli relations. The Obama administration has been silent on Zionism's/Israel's ethnic cleansing of Palestine, and even gone so far as to encourage Palestinians to accept their transfer. It has also encouraged Palestinians to try to build confidence with Israelis and paid for Palestinians to deploy the language of "partnership." Finally, the initiatives of the Obama administration have accelerated the persistent Israeli practice of settlement in the occupied West Bank. As yet another performance of the discourse, the Obama administration's efforts will, in all likelihood, produce more direct Palestinian-Israeli violence and exacerbate Israel's oppressive structural violence against Palestinians.

If any efforts on the part of the Obama administration are to produce PalestinianIsraeli peace rather than more violence, they will have to violate the analytics of the discourse. Peace between Palestinians and Israel is only possible with discursive change, and in order to serve this end the Obama administration must not abide by the discourse, but change it. While it is important to end practices such as Israeli settlement, it is imperative that the analytics according to which the truth of Palestinian-Israeli relations is produced and performed be transgressed. More specifically, the analytic that must be violated is the first silence. In stark contrast to Palestinian negotiator Saeb Erekat, the transfer of Palestinians must not be silenced and accepted, it must be spoken of and challenged. If the Obama administration is truly desirous of Palestinian-Israel peace, it must start to talk about Zionism's/Israel's historical and ongoing ethnic cleansing of Palestine. Only if it breaks this silence will Palestinian-Israeli peace be possible. 